Please quote as: Kunz, M. M.; Bretschneider, U.; Erler, M. \& Leimeister, J. M. (2016): An Empirical Investigation of Signaling in Reward-Based Crowdfunding. In:Electronic Commerce Research, Erscheinungsjahr/Year: 2016. pp. 1-37. 


\title{
An empirical investigation of signaling in reward-based crowdfunding
}

\author{
Michael Marcin Kunz ${ }^{1}$ • Ulrich Bretschneider ${ }^{1}$ • \\ Max Erler $^{1} \cdot$ Jan Marco Leimeister ${ }^{1,2}$
}

(C) Springer Science+Business Media New York 2016

\begin{abstract}
Start-ups often face the challenge of a shortage of capital, the so-called funding gap, which can be overcome by raising small amounts of money from a large number of individuals. As crowdfunding suffers from a continuous rise in failure rates, the aim of this article is to contribute to the research concerning success factors in reward-based crowdfunding campaigns by focusing on signaling theory. Based on data retrieved from the crowdfunding platform Kickstarter, our results indicate that social ties, investment preparation and presentation, the supply of multiple rewards as well as endeavors to communicate and interact with the crowd positively influence the probability of success of a reward-based crowdfunding campaign. In contrast, the funding goal, a campaign's runtime and the estimated time of delivery for the rewards have a negative impact on the successful completion of a campaign.
\end{abstract}

Keywords Success factors · Data analysis - E-business - Signaling $\cdot$ E-commerce Crowdfunding

\section{Introduction}

In the past 5 years, crowdfunding $(\mathrm{CF})$ has gained a lot of attention. In $\mathrm{CF}$, each supporter contributes a relatively small amount of money to a project over an intermediary platform which provides the ecosystem and structure [9]. In general, $\mathrm{CF}$ can be defined as "an open call, essentially through the Internet, for the provision of financial resources either in form of donation or in exchange for some

Michael Marcin Kunz

michael.kunz@uni-kassel.de

1 Information Systems, University of Kassel, Pfannkuchstr. 1, 34121 Kassel, Germany

2 Institute of Information Management (IWI), University of St. Gallen, Müller-Friedberg-Strasse 8, 9000 St. Gallen, Switzerland 
form of reward and/or voting rights" [8]. CF is often used where traditional ways of financing are not available. Besides capital raising, CF entails further benefits, such as community creation, reputation development and idea testing [64]. Depending on the return supporters receive for their funding, four types of $\mathrm{CF}$ are commonly distinguished: (1) Financing projects to receive non-monetary considerations is called reward-based CF. (2) Equity-based CF refers to the financing of start-ups in the form of capital investments. (3) Lending-based CF is understood to be the lending of funds from the crowd to the project initiators. (4) Donation-based CF, as the term 'donation' suggests, refers to financial support without expecting any consideration. In this study, we focus on reward-based $\mathrm{CF}$, as it is the largest category of $\mathrm{CF}$ in terms of the overall number of $\mathrm{CF}$ platforms as well as the raised funding amount in the past years [59].

CF has recently been the subject of many academic studies. Nevertheless, a lot of $\mathrm{CF}$ projects are realized using a trial-and-error approach. It is not fully understood why projects succeed or fail. The need for a better understanding of CF, especially regarding the decisions and actions in each of the three phases of the CF process, exante, during a campaign, and ex-post, has been voiced in the literature [7]. We aim at providing a more comprehensive view on success factors in reward-based CF from a signaling perspective. Such a comprehensive view is needed as CF is becoming an increasingly important alternative funding method. While backers are becoming more experienced, we still observe a decrease in project success rates [47]. We developed a classification of quantifiable signals for reward-based CF and formulated hypotheses regarding the signals' effects on the success rate of a CF campaign. Where possible, we based our hypotheses on CF and signaling literature (see Table 6 in Appendix 1). We will test our hypotheses by looking at 54,913 projects from the largest reward-based CF platform Kickstarter, using binary logistic regression.

In the following, we will develop our hypotheses (Sect. 2), introduce our research method (Sect. 3) and outline our findings (Sect. 4). Finally, we will discuss our results, show which implications for theory and practice our research entails and state which limitations our study is subject to (Sect. 5).

\section{Theoretical background and hypotheses development}

\subsection{Signaling theory and its applicability to reward-based crowdfunding}

Signaling theory analyses different types of signals and situations in which they are used $[60,84]$. It can especially be applied to situations and in which information asymmetries between parties exist [19] and need to be reduced [84]. Information asymmetries can relate to the quality of a service or product or to the other party's behavioral intention, such as the main motivation for selling a product [19]. Markets characterized by information asymmetries can achieve effective exchange when 'above-average' quality product sellers engage in some (costly) effort to signal their quality to the market [70]. Spence [83] states that signals can be considered as "activities or attributes of individuals in a market, which, by design or accident, 
alter the beliefs of or convey information to other individuals in the market" (p. 263).

In e-commerce, signaling plays a substantial role, as consumers have little possibilities to adequately analyze physical product information prior to purchase, leading to information asymmetries [93]. Studies have shown the importance of product presentation mechanisms in e-commerce [43, 53]. The findings include the observation that purchase intentions of consumers and their intention to return to e-commerce sites were influenced by the application of certain technologies and presentation formats [43]. Mechanisms to change the perception, attitude, awareness, and intention of consumers form the center of attention. The format of the product presentation and the information transmitted need to be adjusted to the preferences of potential buyers [54].

To some extent reward-based CF transactions are comparable to e-commerce transactions, especially when backers receive the item produced by the project initiator as a reward for their support. The presentation of projects in pre-purchase $\mathrm{CF}$ shows important parallels to the presentation of products in e-commerce. Both presentations are realized through the Internet as the medium of communication. Further, in many cases the amount of money invested by e-commerce customers and funders will approximately be within the same dimension. Nevertheless, CF transactions differ from those in e-commerce. For instance, a purchase in e-commerce is normally predominately conducted to benefit from the utility of the product purchased, while in CF other incentives, like altruism, play an important role $[12,64]$. Backers are often not only motivated by the reward they will receive but also want to support the development of a product or the realization of an idea [2].

When applying signaling theory to reward-based $\mathrm{CF}$, the parallels to e-commerce are helpful. Project initiators and backers participate in a market with strong information asymmetries. Signals, especially those referring to the quality of a campaign or product, may help to overcome information asymmetries [84]. As projects in reward-based $\mathrm{CF}$ are often of a unique nature, quality signals are important for backers to assess these projects. Project initiators can send signals within the structure provided by the intermediary. The close connection between reward-based $\mathrm{CF}$ and e-commerce allows us to propose a classification of signals based on the framework of website signals established by Mavlanova et al. [60]. Our classification consists of two dimensions: purchase time continuum and signaling cost. We excluded the dimension ease of verification from our classification as our main focus lies on signals that are quantifiable and may be associated with the success of the CF campaign. We further restricted our analysis to signals for which the value which existed at the end of the campaign could be established. Moreover, the question if a signal is considered to be a fake signal is not part of this study [60]. The classification of signals used in our research is not intended to be final or undisputable. There are many more signals that could be included and it is possible that with respect to some campaigns, signals would be assigned to a different category than we do in our general classification (see Table 1). We will therefore abstain from drawing conclusions regarding the effect of individual categories of signals (e.g., comparing ex-ante with during signals). Nevertheless, we consider it 
Table 1 Characteristics of signals in reward-based CF (own illustration according to Mavlanova et al. [60])

\begin{tabular}{llll}
\hline & Pre-funding phase (ex-ante) & $\begin{array}{l}\text { Funding phase } \\
\text { (during-funding) }\end{array}$ & $\begin{array}{l}\text { Post-funding phase } \\
\text { (ex-post) }\end{array}$ \\
\hline Low cost & Reward limit & FAQ count & - \\
& Facebook friends & Facebook buzz & \\
& Description word count & & - \\
High cost & Image count & & \\
& Runtime & Update count & \\
& Reward count & Staff picked & \\
& Backed count & & \\
& Delivery time & & \\
& Video count & & \\
& Homepage & & \\
& Preparation time & \\
\hline
\end{tabular}

useful to provide a classification. The classification enables us to conduct a more structured analysis and, in particular, to provide more structured practical implications at the end of our research. We intend to make our research more accessible for practitioners by showing at which point in time signals are typically used and by indicating (roughly) which level of costs they are associated with. In addition, our classification should be seen as a starting point that leaves room for supplementation and refinement in future research. In the following, we will explain our classification in more detail and provide reasons for the allocation of signals.

The purchase, or in case of reward-based CF the funding time continuum, consists of three phases as proposed by Beaulieu et al. [7]: the pre-funding phase (ex-ante), the funding phase (during-funding) and the post-funding phase (ex-post). Corresponding to the framework of Mavlanova et al. [60], pre-funding signals appear in the beginning of a CF campaign before the main funding phase. Project initiators plan and create their campaign in the beginning by taking different aspects into account, for example, how long a campaign will run or how many rewards will be offered. Immediately at the start of the campaign, these signals will be displayed to the backers. These and other signals sent by the initiator during the funding phase should help backers to evaluate a campaign and make their funding decision. The initiator can send signals in form of project updates while the campaign is running and after. Even in the post-funding phase, the initiator can send signals, for instance on the project realization progress or changes in the delivery time. The second dimension relates to the signal's production costs and is therefore named the "signaling cost" (low/high) dimension [60]. This dimension refers exclusively to the project initiator or the team behind a CF campaign.

Based on this classification, CF campaigns have been analyzed to identify signals that may affect a backer's funding decision. Table 1 indicates our findings. As we only focus on the time span up to the end of a campaign, the post-funding phase remains excluded. Furthermore, as displayed in Table 1, most of the derived signals 
can be found in the pre-funding phase. This can be explained by the fact that the project initiator needs to provide these details at the beginning, prior to the start of the campaign. All of these details can then be assessed by the backer at the beginning of the campaign. We further assigned the signals only to the phase in which they predominantly appear. Nevertheless, it should be mentioned that signals can occur in different phases.

In the pre-funding phase, we consider the reward limitation to be a low-cost signal as applying a limitation to an existing reward is not costly. Another low-cost signal is Facebook friends. We assume that the majority of initiators have an active social media account and that linking this account to the CF campaign is not costly. Further signals in this category are the description word count and the image count. Regarding the latter, producing images of a prototype is less costly than producing a video (high-cost). Producing high-quality videos may involve more people, equipment and time effort (including the time to design an adequate story).

High-cost signals include the runtime of a campaign, the reward count, the backed count, the delivery time, the video count, an external homepage and the preparation time. Producing these signals is costlier than the aforementioned signals. For instance, the longer a campaign runs, the more effort is needed to keep the campaign up-to-date, e.g., providing updates or responding to comments. The reward count is also classified as high-cost for the initiator as it is costly to design rewards. The backed count signal shows the number of other project fundings an initiator is actively involved in. We consider this to be a high-cost signal as the initiator needs to invest money into other projects to increase his backed count. We further classify delivery time as a high-cost signal. We consider "producing" the signal delivery time (meaning getting a product realized and shipped by the determined date) to be costly as short delivery dates lead to a higher work effort for the project team. Preparation time concerns all project initiators in $\mathrm{CF}$ as a campaign needs to be developed prior to the main funding stage. We assume that a longer preparation time reflects a detailed development of a CF campaign and is associated with high costs.

In the second phase, funding phase, we included four signals. The number of FAQ entries is visible to all backers. It is considered to be a low-cost signal as it is relatively cheap to publish text on the campaign website (e.g., compared to producing a video). A further low-cost signal during the funding phase is the Facebook buzz. Creating a buzz over social media is less costly than over other media channels. Update count is a further high-cost signal as frequently producing updates (sometimes in form of pictures and videos) will be rather costly. Finally, staff picked, meaning that a project is prominently listed in a special section compiled by platform's staff is considered to be a high-cost signal. It is costly as only outstanding and unique projects are picked.

\subsection{Determinants of success and signals of reward-based crowdfunding projects}

The signals displayed in Table 1 have their roots in different research streams. The signals "runtime" (campaign duration), "reward count" (number of available 
reward levels) and "update count" are based on CF literature $[64,96]$. For the signal "reward limit" (quantitative limitation of rewards), commodity theory by Brock [10] serves as a theoretical foundation, explaining that the assessment of objects (or goods) depends on how available they are. If goods are rare, the customer considers them as more attractive. The signal "Facebook friends" (number of Facebook friends of the project initiator) is derived from the theory or concept of social capital [69], referring to the size of the personal network of an individual. The signal "backed count" (the project initiator's number of project backings) is grounded in the context of social exchange theory [21]. More specifically, this signal has its root in the principle of reciprocity. The person who has provided a gift or invitation for example is expected to be paid back. This expected obligation helps to build longterm relationships and facilitates exchange processes. The signal "delivery time" is based on the theory of consumption [81]. This research stream suggests that waiting for a product or for a service to consume affects the evaluation of a purchase decision. The signal "Facebook buzz" (the project's social media buzz on Facebook) is based on the principle of "word-of- mouth" (WOM) in communication theory and marketing theory [24, 67]. The signal "staff pick" (presentation of the campaign in the popularity index of Kickstarter) has its roots in the theory of herding behavior [5]. Finally, all other signals discussed in this study "description word count", "image count", "video count", "homepage", "preparation time" and "FAQ count", are discussed on the basis of investment-readiness theory, which is used to shed light on the quality standards of potential business ideas [58].

In the following, we will discuss the considerations behind our hypotheses. The discussion is divided into two sections, which coincide with the categories regarding the time dimension in our classification: ex-ante signals and during-campaign signals. We have ordered the hypotheses within these two sections in a way that hypotheses based on similar theoretical considerations are presented after another (instead of arranging the hypotheses based on the cost dimension). Such theorybased ordering makes it easier to relate the concepts behind the hypotheses to one another.

\subsubsection{Ex-ante signals as success predictors}

The duration of a campaign is defined as the period in which project initiators try to collect financial contributions from the crowd. Kickstarter, for example, proposes a time span of around 30 days [46]. According to Mollick [64], long campaign durations signal a lack of confidence of the project initiators to successfully raise money. Moreover, a long duration may indicate that the project initiator's focus may not be on a fast completion of the CF campaign and thus not proceed as fast as possible. This may reduce the backer's confidence in the project initiator's ability to complete the project in the provided time and quality. A further argument against a long-term campaign is that other CF campaigns with similar features can be initiated on the platform at the same time. This, in turn, can lead to a withdrawal of the funding due to a change in the backers' interest. In addition, it has been observed that CF campaigns are characterized by a special investment dynamic. At the start of a campaign, investments are normally high and later the interest in a campaign 
decreases and investments drop. We therefore expect the positive effect of a long campaign, i.e. the prolonged possibility for the crowd to contribute, to be rather small. Based on these considerations, we hypothesize:

H1 As the campaign duration increases, the probability of project success decreases.

The reward offered in a CF campaign commonly represents the product or service for which the initiator intends to raise funds. Studies from Leite and Moutinho [52] and Carr [13] find an interdependency between the amount of rewards and the success of a campaign. Leite and Moutinho [52] describe this interdependency as negative, meaning that the project's chances to succeed decrease with an increasing number of reward stages. Meanwhile, Frydrych et al. [30] do not find a clear relation between the number of rewards and the project success. Choice as a signal, in form of different reward levels, may signal a project initiator's preparedness as it shows that the initiator tries to provide a range of rewards so that backers can choose a reward that best fits their needs. This may help to attract backers. Offering a range of reward levels might strengthen the freedom of backers and thus increase their intrinsic motivation [87]. Further, empirical evidence shows that consumers are more attracted to those vendors who offer more choices [68]. On the other hand, too many options can have adverse consequences. Research indicates that consumers who can choose from more options invest less than consumers who only have few choices. Consumers who have less choices tend to be more satisfied with a product [68]. We expect that reducing complexity by offering a small number of reward levels may help to reach the funding goal. In addition, the realization of an extensive choice could be hard to handle for the project initiator. Potential funders could therefore doubt whether the project initiator will be able to fulfill the offers as promised. We hypothesize:

H2 As the number of available reward levels increases, the probability of project success decreases.

CF platforms usually offer the option to limit the quantity of rewards offered. Such a quantitative limitation creates scarcity. The evaluation of goods by a customer is affected by the extent of their availability [10]. Goods that are available in low quantities (limited) or can only be obtained at great expense are considered to be more attractive. A shortage in the number of products offered may thus contribute positively to the perception of a product. Scarcity as a signal further serves as an important marketing instrument [86] and creates a sense of uniqueness and distinctiveness among potential good owners [29]. Based on these findings, we argue that in reward-based $\mathrm{CF}$, a shortage in the quantity of offered rewards plays a crucial role in attracting potential backers. Further, a shortage in quantity of rewards, e.g., early bird rewards with considerably low prices, may attract distinctly more backers at the beginning of a campaign compared to a campaign without such a shortage. This further serves as a signal, in form of a funding status progress bar, and thereby to inform other backers that this project is worth being funded [12]. We hypothesize: 
H3 With the presence of quantitatively limited rewards, the probability of project success increases.

$\mathrm{CF}$ intermediaries provide the opportunity to display project initiator related characteristics, including the size of a project initiator's social network, represented by the number of Facebook friends (H4a) and the initiator's prior fundings on the platform (H4b).

The personal network of an initiator is commonly an important element in CF campaigns. It serves as a source of funding and as a way to spread the word about a campaign. In addition, Mollick [64] sees the number of Facebook friends as an indicator for the scope of the personal network of the project initiator. The number of Facebook friends can hint to the initiator's potential to generate support, mobilize collective actions, draw on resources from other members of the social network and build trust [13]. Thus, linking to a social network can help to enhance trustworthiness and benevolence [73, 82]. This is important for transactions over the Internet [90]. Linking to a social network can further serve as a signal that the initiator has a strong incentive not to fail as failure might negatively affect his personal reputation [39]. We hypothesize:

H4a As the size of the social network of the project initiator increases, the probability of project success increases.

Funding campaigns of other initiators may help to build trust and therefore have an impact on backers' willingness to support a CF campaign [22, 25]. It further signals that a project initiator is familiar with the CF process (e.g., frequency of updates), the challenges occurring during or after a campaign (e.g., delayed deliveries), the information needs and concerns of backers and the effects of information (e.g., video, text, pictures) provided in a campaign. Thus, a high involvement of project initiators in other CF campaigns signals a project initiator's expertise [91] which may influence backers' behavior [22]. Based on the experience collected by funding other projects, a project initiator further signals that he is aware of factors that may affect successful project completion. In addition, supporting projects of other initiators can help to attract other initiators and their supporters as backers. It has been shown that project initiators support each other more and more [18]. This may be explained by the observation that the CF community is characterized by a certain degree of reciprocity, a "giving and taking". By supporting other projects, initiators actively take part in this community. We hypothesize:

H4b As the number of projects supported by the project initiator on the CF platform increases, the probability of project success increases.

In the context of online services, delivery time is seen as a critical signal of service quality [75]. Mowen and Mowen [66] show a connection between the time difference between the purchase of a product and its use on the one hand and the initial evaluation of the purchase decision on the other. Leclerc et al. [51] indicate that delays in the provision of a good are seen as a cost factor on the buyer's side. Research shows that delivery time is part of a number of important criteria for 
information search and alternative evaluation which are assessed by buyers when choosing an online merchant within their buying decision process [88]. It has therefore been recommended to online retailers to minimize delivery to signal that ordered and paid goods are on the way to the customer without delay [14]. Further, the delivery time can be understood as a service guarantee in form of a promise made by a seller to deliver products as promised [62], serving as a cue to potential customers about the quality of the service or product offered [3]. Given the similarities between reward-based $\mathrm{CF}$ and e-commerce, the same principles are likely to apply. Project initiators are obliged to set up a delivery date for rewards they offer. The set delivery date is of a rather vague nature and primarily serves as an estimated delivery date. Short delivery times may serve as a signal that a product or a service is close to completion. It further serves as a quality signal that helps to reduce perceived risks and foster perceived trust, thereby influencing funding behavior [31]. CF projects are often characterized by the fact that the reward has not yet been produced. By announcing delivery dates that are close to the end of a campaign, the project initiator signals his confidence and ability to get the rewards realized as promised and on time. Backers searching for new projects may rate a high delivery time as risky, and thus regard the initiator as not prepared enough to get his own project realized. The increased delivery time may serve as a negative signal which may lead to a decreased probability of project success. We hypothesize:

H5 As the delivery time of the promised rewards increases, the probability of project success decreases.

A CF campaign's project description presents a project in detail. Its function is comparable to a start-up's business plan or pitch presentation as it aims at convincing investors. The design and completeness of information of an investment presentation are important factors for obtaining financial resources from investors [56]. Martens et al. [57] argue that the presentation should have an effectively constructed and presented story in order to successfully acquire funding. Further, the importance of communication skills of entrepreneurs to affect the investors' decisions has been emphasized [17]. In CF, the project description is often the main source of information. Such information can be provided through text passages, pictures or videos. A decent project presentation reflects the preparedness of the project initiator, which in turn has a positive effect on perceived quality of the project and on possible investment decisions. The preparedness of the project initiator and the passion towards his project is visible in the presentation of the idea [15]. Both can have a positive effect on investors' decisions. The plethora of product information is a decisive success factor of e-commerce sites [72]. In order to decide on the best possible product option, consumers want all of the accessible information that can improve their perspective in aiding their product rating [71]. A high-quality project presentation can serve as a signal for the project initiator's preparedness and willingness to succeed. It shows that the CF project, in terms of business founding, is designed for durability. It also indicates the initiator's professionalism and may help to foster trust. 
We look at different features of the project presentation which significantly impact trust in the project initiator [34] and can serve as a signal of product quality [93]: the scope of the description (H6a), the number of images (H6b), the number of videos (H6c), the availability of an external project website (H6d), the preparation time before the launch of the campaign (H6e), the FAQ entries (H6f) and the update count (H6g).

The CF process is characterized by information asymmetries between the backer and the project initiator. Backers need to rely on the information provided by the project initiator. One important way to convey information about the project is the project description where a project initiator is able to describe the project in detail. The scope of the description can be seen as one important signal of preparedness towards a backer and thus help the backer to better assess the offered product or service. It may therefore serve as a positive signal which may lead to an increased probability of project success. We hypothesize:

H6a As the scope of the description on the project site increases, the probability of project success increases.

The visual appeal of a website plays a crucial role in the consumer's decision process [55]. Vividness in general influences the quality of the product presentation [43] and includes methods by which the surrounding information is presented to the senses [85]. A vivid product presentation can relay more information and thereby stimulate a variety of sensory channels by employing different multimedia formats [44]. Such formats include pictures and videos. Processing of a voluminous amount of information can be supported through the utilization of vivid presentation formats which in turn can lead to a better understanding of the project. Visually appealing images show an initiator's preparedness to offer a high quality reward. With an increase in the number of images, a backer is better able to assess a project's main intention and functionalities, especially the rewards. We hypothesize:

H6b As the number of images used on the project site increases, the probability of project success increases.

In a video, a project initiator usually displays the product or service that is being funded; he talks about his aim, and he provides further information about himself and his experience. A project initiator can further give detailed information about his desire to make the project come true. In sum, this makes the funding process more trustworthy, as well as the project initiator more authentic. The project initiator appears more personal and human, thus reduces the distance between him and the backers. The number of embedded videos may thus serve as a positive signal which may lead to increased probability of project success. We hypothesize:

H6c As the number of embedded videos on the project site increases, the probability of project success increases.

A source of additional information is an external website on which a project initiator can provide further information about the project. The creation of an external website also allows for the inclusion of further functionalities, such as voting on stretch goals to better communicate with the (potential) backer. Project 
initiators are usually restricted to the functionalities provided by the crowdfunding website. An external website can therefore increase their options of communicating with the crowd. It further signals that a project initiator's aim may not be to realize a single campaign but to start a business. Therefore, having an external website may be perceived as a positive signal which may lead to increased probability of project success. We hypothesize:

H6d With the availability of an external website, the probability of project success increases.

A project initiator is able to create his project page at any time prior to the start of the campaign. It is only visible to the initiator and persons invited. In order to successfully raise funds in the end, a project initiator is recommended to continuously improve the campaign by testing and improving its quality. Doing so signals that the campaign has been developed and tested over a longer time period by the project initiator. As a longer preparation time signals an initiator's preparedness and determination, we expect that it increases the probability of project success. The preparation time is embedded in the html-code of the project site. Apart from this, it cannot be directly seen by backers. The preparation time is, however, reflected in the quality of the project page which can serve as an indirect indicator of preparation time. We look at the preparation time embedded in the html-code as a proxy for the indirectly observed preparation time. We hypothesize:

H6e As the preparation time of the project increases, the probability of project success increases.

\subsubsection{During-campaign signals as success predictors}

Using the FAQ section and continuously expanding it with new entries signals to the crowd that the initiator is prepared, committed, and willing to make the funding process more transparent. We expect that an extensive FAQ section helps backers to assess the needed information better. The more extensive a project's FAQ, the more crucial the information it may provide to potential backers. Moreover, this information is easily accessible and can therefore help to evaluate the project. FAQs mostly arise over time from questions and requests from backers [45]. Those questions may concern shipment, functionality, service, safety issues, etc. [78]. Further, FAQ are a more efficient way for backers to deal with common questions and concerns than individual communication. E-commerce literature found evidence for the importance of an FAQ section by showing that online stores with an FAQ section receive more visits from buyers than those without [78]. We hypothesize:

H6f As the number of entries in the FAQ on the project site increases, the probability of project success increases.

For project initiators, updates present a way to inform their backers about the progress of the campaign. Updates appear separately on the project page or in form of a personal message to all backers who have already made a financial contribution. 
Kuppuswamy and Bayus [50] see updates as a decisive factor concerning the investment dynamic, especially in the beginning and in the end of a campaign. Updates during a campaign help project initiators to stay in touch with the crowd, to present new insights on the project's progress and to communicate further information. Information can include the current state of the project or new features that will be unlocked when a funding threshold is reached. Furthermore, the project initiator may offer backers a voting mechanism for new project features. Doing so helps to transform the distanced and unpersonal funding process into a more personal one. Updates can strengthen the relationship between the initiator and the crowd, and hence lead to a higher degree of trustworthiness. Gefen and Straub [32] found that perceived social presence positively influences trust and reduces perceived risks and can further ensure the consumer intent to purchase. The exchange of information and the communication during a campaign in form of updates can create a unified consensus, which could lead to fun and excitement on the backers' side. This communication helps to reduce information asymmetries between involved parties [65]. We hypothesize:

H6g As the number of updates during the campaign increases, the probability of project success increases.

Word of mouth advertising ("Word-of-mouth" or WOM) refers to the oral deliverance of messages between consumers [67]. This type of communication is highly effective in influencing consumers' behavior and consequently their purchasing decision [6, 24, 27, 40]. The eWOM (electronic word-of-mouth) is associated with the concept of viral marketing which induces customers to independently propagate the (advertising) message without any further intervention from the outside [38]. The Internet as a communication tool facilitates social exchange and interactive communication between users, in particular by means of social media platforms $[38,80]$. CF intermediaries provide functions that allow the project initiator to communicate with backers. Kickstarter, for instance, offers project initiators the opportunity to share their CF campaign via Facebook and Twitter. The informational exchange through social networking is referred to as "Buzz" (to be understood similar to mumble or chatter). Jansen et al. [42] see Twitter as a pronounced approach of branding. They demonstrate that social networks are effective in generating brand awareness and influencing brand perception. Asur and Huberman [4] use Twitter messages for the purpose of prediction, for instance to estimate the sales of forthcoming cinema movies. With the integration and use of social networks in the CF campaign, the social "Buzz" (hereinafter referred to as social media buzz) for a project can be captured. An increased social media buzz can serve as a positive signal that may lead to a higher number of financial contributions and, finally, to increased probability of project success. We hypothesize:

H7 As the social media buzz increases, the probability of project success increases.

To simplify the search of new and interesting projects, platforms offer special search mechanisms and filters. On Kickstarter, staff members post a selection of 
chosen projects from all thematic areas on the platform's homepage. The criteria of such a staff selection are based on subjective characteristics, such as how interesting a project is to a staff member or whether a thrilling idea is being introduced. Furthermore, a project can be highlighted as the 'project of the day'. Next to the staff selection, projects can further appear in the category of especially popular projects, which also helps making them noticeable on the homepage. Staff-picked projects are not only listed in a further search category, but also get a badge on their project's description page. This badge serves as a seal of approval, thus signaling that a project is particularly trustworthy [28]. CF projects are usually not reviewed by platform operators before being published and thus remain risky for potential backers. A listing in the popularity index by members of the platform operating team may decrease backers' perceived risk. Further, according to the concept of herd behavior, backers will make their (investment) decision based on the judgment of others, here the Kickstarter staff, instead of relying on their own information. We therefore expect that being highlighted in the popularity index can serve as a positive signal that may lead to increased probability of project success. We hypothesize:

H8 By highlighting the campaign in a popularity index, the probability of project success increases.

Table 2 summarizes our hypotheses by displaying the variables, the associated description as well as the direction of the assumed effect between the variables and the successful project completion in reward-based CF. Moreover, it highlights hypotheses that have not been addressed in prior research. A visual presentation of the variables used to test our hypotheses can be found in Figs. 2, 3 and 4 in Appendix 2. In addition, in Table 2 we provide information on further variables we collected through our analysis. All these variables, except for StateValue, were used for descriptive statistics. StateValue is the dependent variable of our research.

\section{Research method}

We collected our data on the CF platform Kickstarter. Since Kickstarter is not available through a public application-programming interface (API), information on $\mathrm{CF}$ projects and their characteristics (Table 2) has been collected using a web crawler and has been stored in a database. The funding goal of a project is included in the investigation as a control variable. Overall, our database includes 136,886 projects. As part of the data cleansing process, erroneous records, duplicates, 12,011 canceled, 259 suspended and 6042 projects in progress were removed. 116,863 projects remained for further analysis. In contrast to the study of Mollick [64], projects outside the US were not excluded from the analysis. All currency-related values were converted into US-Dollar (US\$). ${ }^{1}$ A look at the homepage-category revealed that in some cases backers used various websites as a form online presence, for example a personal Twitter account or a YouTube channel. Since this does not

\footnotetext{
$\overline{1}$ Based on the conversion rates of 13 October 2014 and 14 October 2014.
} 
Table 2 Overview of variables considered in this study (own illustration)

\begin{tabular}{|c|c|c|c|c|c|}
\hline Hypothesis & Variable (label) & & Description & $\begin{array}{l}\text { Direction } \\
\text { of effect }\end{array}$ & $\begin{array}{l}\text { New } \\
\text { hypotheses }\end{array}$ \\
\hline $\mathrm{H} 1$ & Runtime & & $\begin{array}{l}\text { Campaign duration } \\
\text { (in days) }\end{array}$ & - & \\
\hline $\mathrm{H} 2$ & RewardCount & & $\begin{array}{l}\text { Number of } \\
\text { available reward } \\
\text { levels }\end{array}$ & + & \\
\hline $\mathrm{H} 3$ & RewardLimit & & $\begin{array}{l}\text { Quantitative } \\
\text { limitations of } \\
\text { rewards (yes/no) }\end{array}$ & + & $\mathrm{X}$ \\
\hline $\mathrm{H} 4 \mathrm{a}$ & FacebookFriends & $\begin{array}{l}\text { Project initiator } \\
\text { characteristics } \\
\text { (H4) }\end{array}$ & $\begin{array}{l}\text { Number of } \\
\text { Facebook friends } \\
\text { of the project } \\
\text { initiator }\end{array}$ & + & \\
\hline $\mathrm{H} 4 \mathrm{~b}$ & BackedCount & & $\begin{array}{l}\text { Number of project } \\
\text { backings of the } \\
\text { project initiator }\end{array}$ & & \\
\hline H5 & AvgDelDateDiffGew & & $\begin{array}{l}\text { Weighted average } \\
\text { delivery time (in } \\
\text { days) }\end{array}$ & - & $\mathrm{X}$ \\
\hline H6a & DescriptionWordCount & $\begin{array}{l}\text { Preparedness of } \\
\text { presentation } \\
\text { (H6) }\end{array}$ & $\begin{array}{l}\text { Number of words } \\
\text { used on the } \\
\text { campaign site }\end{array}$ & & \\
\hline H6b & ImageCount & & $\begin{array}{l}\text { Number of images } \\
\text { used on the } \\
\text { campaign site }\end{array}$ & & \\
\hline H6c & VideoCount & & $\begin{array}{l}\text { Number of videos } \\
\text { used on the } \\
\text { campaign site }\end{array}$ & & \\
\hline H6d & HpValue & & $\begin{array}{l}\text { Availability of a } \\
\text { project home } \\
\text { page (yes/no) }\end{array}$ & + & $\mathrm{X}$ \\
\hline H6e & Preptime & & $\begin{array}{l}\text { Preparation time } \\
\text { (in days) }\end{array}$ & & $\mathrm{X}$ \\
\hline H6f & FaqCount & & $\begin{array}{l}\text { Number of entries } \\
\text { in the project } \\
\text { FAQ on the } \\
\text { campaign site }\end{array}$ & & $\mathrm{X}$ \\
\hline H6g & UpdateCount & & $\begin{array}{l}\text { Number of } \\
\text { released updates }\end{array}$ & & \\
\hline H7 & FacebookBuzz & & $\begin{array}{l}\text { Social media buzz } \\
\text { of the project on } \\
\text { Facebook }\end{array}$ & + & $\mathrm{X}$ \\
\hline H8 & Staffpicked & & $\begin{array}{l}\text { Presentation of the } \\
\text { project in the } \\
\text { staff pick (yes/ } \\
\text { no) }\end{array}$ & + & \\
\hline
\end{tabular}


Table 2 continued

\begin{tabular}{|c|c|c|c|}
\hline Hypothesis Variable (label) & Description & $\begin{array}{l}\text { Direction } \\
\text { of effect }\end{array}$ & $\begin{array}{l}\text { New } \\
\text { hypotheses }\end{array}$ \\
\hline \multicolumn{4}{|l|}{ Further collected variables } \\
\hline FundingGoal & $\begin{array}{l}\text { Targeted amount } \\
\text { of money to } \\
\text { realize project }\end{array}$ & & \\
\hline PledgedMoney & $\begin{array}{l}\text { Received amount } \\
\text { of money from } \\
\text { backers }\end{array}$ & & \\
\hline FundingRatio & $\begin{array}{l}\text { Level of funding } \\
\text { (in percent) }\end{array}$ & & \\
\hline
\end{tabular}

correspond to the nature of a website, these entries were filtered out during the data cleansing process. ${ }^{2}$ As a criterion for success, the funding status was recorded (yes/ no) as a dummy variable. The same applies to the variables HpValue, Staffpicked and RewardLimit, which assume the value one in case of an occurring event and nil in its absence.

To code the variable RewardLimit, all reward levels of a project were recorded and checked. If at least one of the reward categories was quantitatively limited, this criterion was assumed to be fulfilled. The campaign duration is calculated as the difference between start and end date of the campaign. Furthermore, the crawler collected the filing date for the founding account on Kickstarter and the date the project was created. Based on this we were able to determine the time needed for the preparation of the campaign. With regard to the quantitative assessment of the project updates, it should be noted that only those entries were collected and counted that were published during the campaign (during-campaign phase). The measuring of the social media buzz is operationalized using Facebook. Using the share feature of the $\mathrm{CF}$ platform, the link to the project can be provided with a personal message before sharing the message on Facebook with selected friends. In addition, the project can be commented by Facebook users or provided with a "Like". Liking a Facebook message can be seen as an indicator of positive feedback. The combination of these three variables results in the variable FacebookBuzz. The variable of the delivery period (AvgDelDateDiffGew) is determined with the help of the weighted arithmetic mean. The reason for this is the variety of reward levels that have significantly different delivery times. However, due to the level utilization not all rewards are equally relevant. In such cases a never or rarely picked reward with a highly deviating delivery time represents an outlier value, and thus may lead to a distributional skewness. Accordingly, it is the goal of the weighted arithmetic mean to have delivery times of different reward levels incorporated in the calculation, in accordance with their importance to the project.

\footnotetext{
${ }^{2}$ Following terms and symbols were looked upon for the filtering: Facebook, LinkedIn, Twitter, YouTube, Twitch, Flickr, Tremblor, Imbd, Soundcloud, iTunes, Vimeo, Instagram, WordPress, BlogSpot, Myspace, Deviantart, about.me, etsy, @, Wikimedia, Wikipedia, Bandcamp, Reverbnation, Blog, youtu.be, Google, google.com, plus.google, docs.google, picasaweb.google, profiles.google, Aboutme, bit.ly, user,/profile, Reddit, Yahoo, Amazon.
} 
This is accomplished with the aid of a weighting factor. The following formula was used for the calculation of the weighted arithmetic mean of delivery time $\mathrm{m}^{3}$ :

$$
\mathrm{m}=\frac{\sum_{b} L(b) \times \mathrm{P}(b) \times \mathrm{b}}{\sum_{b} P(b) \times b}
$$

The weighting factor $\mathrm{P}(\mathrm{b}) \times \mathrm{b}$ takes into account that the expected total payment amount is a decisive factor in importance of a reward level, that also depends on both, the willingness to pay and the amount of each payment. The willingness to pay $\mathrm{P}$ (b) is across all projects empirically determined from all Kickstarter payments. It is defined as:

$$
P(b)=\sum_{j}^{a_{j} \geq b} h_{j}
$$

In this formula $a_{j}$ are the possible characteristics of the payment amount and $h_{j}$ are the associated relative frequencies. The calculation is based on the assumption that someone who is willing to pledge, for example US\$20, would also pledge any lower amount. $\mathrm{P}(\mathrm{b})$ is to be understood as a probability (see Fig. 1 for a log scale visual representation of $\mathrm{P}(\mathrm{b})$ ) for a certain amount to be pledged. With increase in the level of contributions, the willingness to pay rapidly approaches zero. This can be expected since the principle of CF essentially means aggregation of many small payments. Thus, extensive contributions only rarely occur.

Due to the coding of the dependent variable (Value State), the analysis is performed using binary (logistic) regression. Compared to the linear regression, the probability of the occurrence of an event (dependent variable) is derived in the course of the (binary) logistic regression. The level is not estimated in terms of expected observations. In case of a dichotomous dependent variable, this event reveals two possible forms (two-group case). Based on the influencing factors, it is distinguished, with which probability an observation case related to the given theme (involving a CF project) can be assigned to a specific characteristic in this twogroup case $(0=$ project failure, $1=$ project success $)$ [36].

Due to the wide dispersion of their characteristic values, we performed a logarithmic transformation with respect to the variables FundingGoal, FacebookFriends, DescriptionWordCount, BackedCount, Preptime, AvgDelDateDiffGew and FacebookBuzz. The logarithmic transformation was carried out using the common logarithm. Furthermore, in line with Mollick [64], projects with extreme values for the funding goal were excluded. This included projects for which the funding goal was below US $\$ 100$ (resulting in deletion of 680 projects) or over US $\$ 1,000,000$ (resulting in deletion of 169 projects). In addition, records with missing values were excluded from the regression analysis. Finally, 54,913 projects from April 2009 to July 2014 were included in the analysis. For the evaluation, we

\footnotetext{
${ }^{3}$ Where the notations are: $\mathrm{b}=$ Payment amount for the reward level; $\mathrm{L}(\mathrm{b})=$ Delivery time for amount $\mathrm{b} ; \mathrm{P}(\mathrm{b})=$ Willingness to pay amount $\mathrm{b}$.
} 


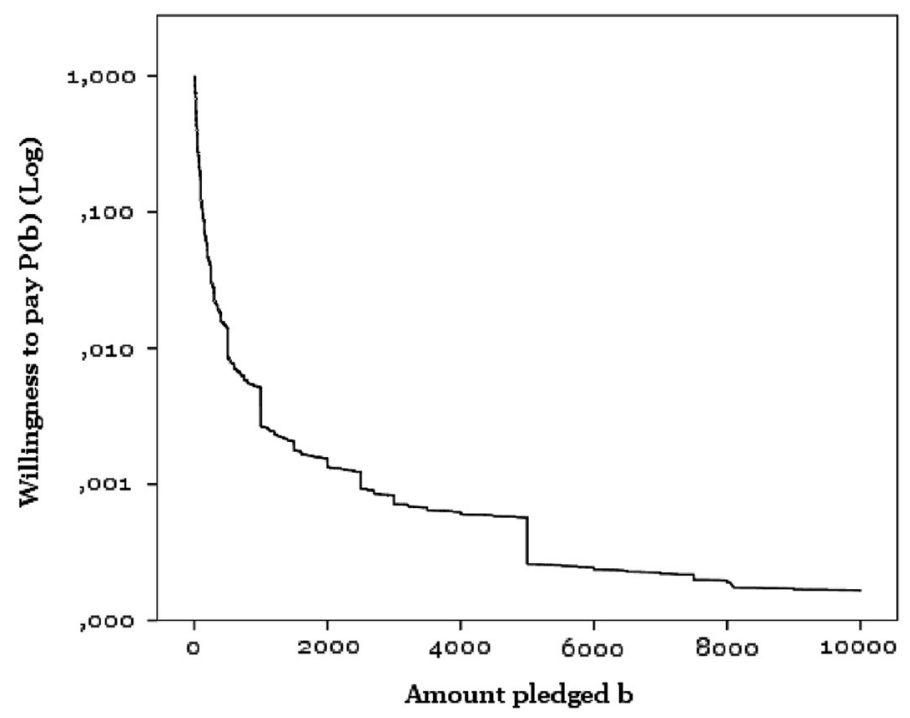

Fig. 1 Visual representation of the willingness to pay on Kickstarter (own illustration)

used SPSS version 21. The regression model was determined based on the inclusion method.

\section{Findings}

\subsection{Descriptive statistics}

Table 3 contains the central variables of our analysis. It should be noted that the results described in this section are based on a different sample size than the regression analysis. Data for the binary logistic regression had to be cleansed, resulting in a reduced sample size of $n=54,913$ compared a sample size of $\mathrm{n}=116,863$ for the descriptive statistics. Overall, during the period from April 21, 2009 till July 20, 2014, a total sum of US\$ 1,047,642,617 has been collected from $13,720,831$ backers in 116,863 projects. It should be noted that this does represent the number of unique project supporters because individuals sometimes support several projects. The overall success rate was $46.13 \%$. The average amount raised per project was US\$ 8965 and was collected from an average of 117 backers. The average contribution per backer amounts to US\$ 76.35. The maximum campaign duration allowed by Kickstarter is 60 days but the average across all analyzed projects was 34.45 days. The average time for a project's preparation period prior to being published was 37.43 days. Analyzing design variables revealed that the average number of videos used per project was 1.1, the average number of images in a project presentation was 4.2 and the average number of words in a project description amounted to 653.26 . The majority of projects $(60.5 \%)$ had their own separate website. $60.2 \%$ of projects implemented a limitation of rewards. The 
Table 3 Descriptive statistics of total sample (own illustration)

\begin{tabular}{lllrrrr}
\hline Variable & N & Min & \multicolumn{1}{l}{ Max } & \multicolumn{1}{l}{ Mean } & SD & Mode \\
\hline FundingGoal & 116,863 & 0.893 & $100,000,000$ & $21,272.179$ & $380,055.127$ & 5000 \\
PledgedMoney & 116,863 & 0 & $10,266,846$ & 8964.708 & $73,760.519$ & 0 \\
FundingRatio & 116,863 & 0 & 41,535 & 2.025 & 154.761 & 0 \\
PledgeRatio & 108,089 & 0.786 & 10,000 & 74.192 & 121.418 & 25 \\
BackerCount & 116,863 & 0 & 91,585 & 117.41 & 871.124 & 0 \\
FaqCount & 116,863 & 0 & 51 & 0.63 & 1.908 & 0 \\
RewardCount & 116,863 & 0 & 227 & 8.81 & 5.542 & 7 \\
BackedCount & 100,366 & 0 & 1185 & 4.95 & 16.712 & 0 \\
FacebookFriends & 100,366 & 0 & 5981 & 489.74 & 807.974 & 0 \\
UpdateCount & 116,863 & 0 & 147 & 3.13 & 5.138 & 0 \\
Preptime & 116,863 & 0 & 1416 & 37.47 & 74.826 & 0 \\
Runtime & 116,863 & 1 & 91 & 34.45 & 13.603 & 30 \\
AvgDelDateDiffGew & 100,377 & 0 & 1982 & 93.438 & 108.163 & 0 \\
VideoCount & 116,863 & 0 & 39 & 1.10 & 1.036 & 1 \\
ImageCount & 116,863 & 0 & 174 & 4.20 & 7.735 & 0 \\
DescriptionWordCount & 116,863 & 1 & 30,950 & 653.26 & 578.202 & 339 \\
FacebookBuzz & 116,863 & 0 & 266,105 & 90.18 & 1021.886 & 0 \\
KsExperience & 100,366 & 0 & 2017 & 165.803 & 277.092 & 0 \\
\hline
\end{tabular}

average amount of reward options offered per project was 8.81 . The average rate of all projects selected as staff picks by Kickstarter employees was $8.8 \%$.

The number of campaigns carried out in relation to launches and completions, shows a recurring pattern at both, the beginning and ending of the year. During the winter months there is a decrease in new and completed projects; in the beginning of December: $\mathrm{n}=7053(6 \%)$; in the end of December $\mathrm{n}=9269(7.9 \%)$; in the beginning of January: $\mathrm{n}=9.126(7.8 \%)$; in the end of January $\mathrm{n}=7457(6.4 \%)$; in the beginning of February $n=10,011$ (8.6\%); in the end February $n=7867$ $(6.7 \%)$. During spring and summer, more projects are launched and completed. The month of May constitutes the climax and can be considered as the busiest month on Kickstarter; beginning of May: $n=11,648$ (10\%); end of May: $n=12,258$ $(10.5 \%)$. In autumn, the number of projects decreases. Further descriptive data can be retrieved from Table 3 in Appendix 3.

\subsection{Hypotheses testing}

The results of the regression analysis are displayed in Table 4. The regression coefficients $\beta$ indicate the direction of influence between the success criterion (dependent variable) and each signal (independent variable), and can be used as a means for hypotheses testing. The corresponding effect coefficient (odds ratio) is determined by computing the antilog of the regression coefficients. The corresponding 95\% confidence interval is used to assess the direction of influence of the effect coefficients. If the confidence interval reaches values higher and lower than 
Table 4 Results of the regressions analysis (own illustration)

\begin{tabular}{lrlllll}
\hline Variable & \multicolumn{1}{l}{$\beta$} & Exp $(\beta)$ & SE & $95 \%$ CI & Hypotheses \\
\hline Runtime & -0.015 & 0.985 & 0.001 & 0.983 & 0.987 & H1: accepted \\
RewardCount & 0.051 & 1.053 & 0.003 & 1.047 & 1.058 & H2: rejected \\
RewardLimit & -0.181 & 0.835 & 0.024 & 0.796 & 0.875 & H3: rejected \\
FacebookFriends (Log) & 1.156 & 3.178 & 0.026 & 3.023 & 3.342 & H4a: accepted \\
BackedCount (Log) & 0.938 & 2.555 & 0.027 & 2.422 & 2.695 & H4b: accepted \\
AvgDelDateDiffGew (Log) & -0.082 & 0.922 & 0.018 & 0.890 & 0.954 & H5: accepted \\
DescriptionWordCount (Log) & 0.455 & 1.576 & 0.040 & 1.458 & 1.703 & H6a: accepted \\
ImageCount & -0.030 & 0.970 & 0.002 & 0.967 & 0.974 & H6b: rejected \\
VideoCount & 0.050 & 1.051 & 0.011 & 1.029 & 1.074 & H6c: accepted \\
HpValue & 0.261 & 1.298 & 0.023 & 1.241 & 1.358 & H6d: accepted \\
Preptime (Log) & 0.181 & 1.198 & 0.018 & 1.156 & 1.242 & H6e: accepted \\
FaqCount & 0.072 & 1.074 & 0.007 & 1.060 & 1.089 & H6f: accepted \\
UpdateCount & 0.206 & 1.229 & 0.004 & 1.219 & 1.238 & H6 g: accepted \\
FacebookBuzz (Log) & 0.419 & 1.521 & 0.011 & 1.487 & 1.555 & H7: accepted \\
Staffpicked & 0.844 & 2.326 & 0.043 & 2.138 & 2.531 & H8: accepted \\
FundingGoal (Log) & -1.869 & 0.154 & 0.025 & 0.147 & 0.162 & \\
Constant & 1.055 & 2.873 & 0.131 & & & \\
\hline
\end{tabular}

Remarks: SE Standard Error. All model coefficients are highly significant at a significance level of $\alpha=0.01$. The model relevance is marked as good in accordance with Nagelkerke- $\mathrm{R}^{2}=0.467$; Statistic reliability (model fit) was tested using the Likelihood-ratio test (LR test). At $16 \mathrm{df}$, the Chi square value amounts to 23,686.134, leading to rejecting the null hypothesis (significance level of $1 \%$ ). The computed regression model is statistically significant relating to data and in terms of its explanatory power

one at the same time, the direction of influence is seen as insecure. For values that are far apart from each other, the strength of influence is considered as uncertain [61]. For all coefficients from our model the direction of influence is clear without any ambiguity. The same can be applied to the strength of influence. Further, the regression model is tested for multicollinearity with the help of computed standard errors (SE in Table 4) and the correlation matrix (see Table 8 in Appendix 4). High standard errors (non standardized: $>2$, standardized: $>1$ ) as well as correlation values between independent variables of approximately 0.70 indicate multicollinearity $[26,61]$. The greatest standard error is 0.043 for $\times 9=$ Staffpicked. Checking the correlation matrix, no correlation value exceeds 0.3 . We can therefore argue that multicollinearity is not problematic in this examination.

\section{Discussion}

To systematically categorize the signals examined in our study, we have classified them along two dimensions: funding time continuum and signaling costs. With respect to the funding phase, we found a positive effect of a large number of signals $(73 \%)$ on the probability of success in the pre-funding phase. In the funding phase, all signals examined had a positive influence on the probability of success. These 
results should not be misinterpreted as meaning that signals in the pre-funding phase are more effective. Such a conclusion cannot be drawn as the results mentioned do not consider the strength of the effect and as the number of signals analyzed is fairly low. Our results imply, however, that the probability of success can be influenced by sending signals both in the pre-funding phase and in the funding phase. With respect to signaling costs, a large share of low cost signals (67\%) and an even larger share of high cost signals $(89 \%)$ had a positive effect on the probability of success. Due to the same reasoning as mentioned before, these findings do not imply that high cost signals are more effective than low cost signals. They show, however, that even with small costs signals can be provided that significantly increase the probability of success of a crowdfunding campaign.

For the relationship between the number of rewards and the probability of success, the analysis shows that the coefficient of the independent variable RewardCount is positive. This finding contradicts our theory-based expectation and the findings of Leite and Moutinho [52] who state that projects should have a rather compact reward structure. It should be noted, however, that Leite and Moutinho [52] use "level of funding" as a criterion for success, while we use the final funding status. Our finding regarding the relationship between the number of reward levels and the successful funding of a project can be justified on the basis of the concept of price differentiation which, based on given differences between the amounts of investment (with each reward level having its own price level connected to it), can be applied to reward-based CF. Different or discriminatory prices play an important role in optimizing the allocation of resources and therefore the efficiency of markets [74]. On Kickstarter, the different reward levels are connected to different amounts of pledges (an equivalent to prices) which are equal for all potential backers. Cholakova and Clarysse [16] point out that providing attractive rewards in the course of a CF campaign is crucial for project success, whereby the reward ideally resembles the product or service offered. It can further be argued that the more (different) rewards a project offers, the more options a potential backer has to pick from which ultimately results in more financial support. Conversely, this means that limiting the backers' choices would decrease a campaign's likelihood to succeed. It follows that the project initiators need to develop the campaign's reward structure carefully and test it, regarding the amount of awards or product properties (color, size, etc.) during the preparation phase. The rewards should also reflect the campaign's product or service and should supplement the creation of a community via rewards. Non-material compensation alone, including public recognition or saying "thank you", is likely not to be sufficient.

With respect to scarcity of rewards, we did not find the expected positive effect on probability of success. The negative relationship found in our analysis may be explained by the consideration that a quantitative shortage of rewards may decrease the attractiveness of a campaign. It is conceivable that if a particularly attractive reward is already sold out shortly after the start of the campaign and other rewards of the campaign remain uninteresting to the crowd, the project becomes less appealing for other potential backers.

The positive effect between an initiator's prior funding experience and the probability of success of his own campaign, as suggested by the studies of Zvilichovsky et al. [96] and Colombo et al. [18], becomes especially important on the 
basis of the principle of reciprocity. On Kickstarter, for instance, in the so-called "Kicking It Forward" initiatives, members on Kickstarter constitute a community and are directed to support each other. Since the degree of commitment in terms of project backings from the project initiator is publicly available, potential backers can use this information to firm up their decision to pledge. If a project initiator is firmly rooted in the Kickstarter community, this leads other members to acknowledge this commitment and in turn promote the respective project. Therefore, new project initiators are advised to establish and expand upon these networks.

The hypotheses formulated regarding the information provided on a reward-based project website (H6) argue that these variables signal the preparedness of the project initiator and, as a result, have a positive effect on the probability of success. This expectation has been confirmed for all hypotheses except H6b. One can only speculate how the negative effect of image count on probability of success can be explained. It is possible that an excessive use of images results in a cluttered campaign page and eventually leads to an unpleasant appeal or an interference with readability. It is likely that the level of image quality has an influence as well. Low image quality may deter backers by reflecting a negligent preparation from the project initiator's side. Nevertheless, project initiators are encouraged to include selected high quality images which contribute to the understandability of the project's description. According to the provision of information, a project initiator should make sure to describe the project as detailed as possible. They should provide details on the planned approach, objectives (based on milestones), proposed distribution of funds, the project team (career info, expertise, references), the story behind the idea, and the reward structure backers are going to receive in return for their contribution. This foundation should provide confidence and signal backers that the project's objective will be met. An overly brief description runs the risk of leaving the crowd feeling in the dark, which may cause uncertainties regarding promises of provision and payments. If questions arise despite a detailed project description, they should be addressed in a public FAQ section of the website.

\section{Contribution to theory and practice}

Our study analyzed the effects of signals in reward-based CF on a successful project completion. We based our study on signaling theory by providing a classification of signals for reward based CF. In our study, we especially focused on the signals that are quantifiable. Based on the real-world data extracted from Kickstarter and a literature review (see Table 6 in Appendix 1) on success factors in reward-based $\mathrm{CF}$, we selected 15 signals for analysis.

\subsection{Theoretical contribution}

We identified six additional signals that have thus far not been covered in the CF literature. These six signals are the impact of the scarcity of rewards, the planned delivery time of rewards, the availability of a project home page, preparation time, number of entries in the project FAQ and social media buzz. With our analysis regarding these signals, we were able to provide new insights to the body of knowledge in reward- 
based CF. In addition, we also analyzed signals that have been the subject of analysis in previous studies. By doing so, we updated existing findings on success factors in rewardbased CF. As CF is getting more mature and backers more experienced (positive and negative experience) it is possible that already identified success factors might have changed over time. Our findings contradict prior research regarding one signal (offered reward levels). Although Leite and Moutinho [52] argue that a compact reward structure serves as a success factor, we observed the opposite effect.

Our literature review makes a further theoretical contribution. Firstly, the results of the review sum up current research activities on success factors in reward-based CF. Secondly, the results allow us to identify new fields of research that have not been addressed yet. For instance, as indicated by the results of the literature review, most studies concerning success factors in reward-based $\mathrm{CF}$ are of a quantitative nature and make use of regression analysis. Despite their importance, it would be valuable for CF research to gain deeper insights from qualitative studies as well. Potential future approaches include interviews and case studies. From both a qualitative and a quantitative perspective it would further be useful to have more studies that research the rationale behind the factors that explain backers' funding behavior.

It is still not fully understood why some projects succeed while others fail [7]. Beaulieu et al. [7] suggest a number of factors that can be found in the three main phases of a CF process: ex-ante, during a campaign, and ex-post and describe the decisions and actions made in those phases. These contain among others, the design and preparation of a CF campaign (ex-ante), the facilitation to help to get to know projects during a campaign or the fulfillment of shipping the offered rewards (expost) [7]. By proposing a classification of signals for reward-based $\mathrm{CF}$, we were able to identify signals for the ex-ante and during-campaign phase that may affect the success of a reward-based CF campaign. Given the fact that our analysis is based on signaling theory, we further contribute to this research stream by applying signaling theory to a new field of interest, and thus by creating new insights for both, research on signaling and on CF theory. By providing a classification for success signals in reward-based $\mathrm{CF}$, we especially contributed to the research streams of signaling theory. Overall, our results indicate that signaling theory is applicable in the context of this study. Based on this theory stream and especially based on signals used in e-commerce, we were able to derive our hypotheses and finally conduct our analysis. We argue that reward-based CF shares some of the signaling characteristics of e-markets and e-auctions and thus is comparable to e-commerce transactions to some extent. We thus consider e-commerce literature to be a suitable starting point to develop theory with respect to reward-based $\mathrm{CF}$, for instance to help understand backers' behavior and how their funding is affected by perceived risks, perceived trust, or other core theories from e-commerce literature.

We proposed a classification of signals for reward-based CF. Researchers are encouraged to evaluate, revise and extend this classification of signals to provide deeper insights on success signals in reward-based CF. This might help project initiators to determine, which factors are useful in which phase of the CF transaction. It will further help project initiators to better target the crowd to achieve financial support. For the moment, we classify signals based on the time continuum and the production cost of a signal (high/low). Our classification can, however, be 
extended by further dimensions, for example a qualitative dimension such as pointing signals and activating signals, as well as the ease of verification (easy/ difficult) of a signal from a backer's viewpoint. The latter refers particularly to the ability of a backer to consider whether a signal is a fake signal or not [93].

\subsection{Practical contribution}

From a practical perspective, our findings have manifold implications for project initiators as well as for CF intermediaries. Based on our findings, project initiators are provided with a set of signals, subdivided into the two main phases in $\mathrm{CF}$, and clustered according to the production cost of the respective signal. This classification of signals provides a basis for project initiators when to announce which signal. Further, our findings indicate that not all of the signals analyzed may lead to a successful project completion. Project initiators should therefore choose signals or sets of signals wisely, based on the goal they aim to achieve (for example informing backers, activating backers funding behavior, etc.). The reasoned application of such signals, can serve as a quality sign, in the sense that the campaign is well prepared. A well-prepared and structured campaign may lead to a reduction in perceived risks, due to the limitation of information asymmetries between the backer and the campaign initiator. We advise project initiators to send signals in the pre-funding as well as in the funding phase to increase the probability of success of a project. Our results further show that a couple of signals can be sent at low costs and will still increase the probability of success of a CF project. Such signals are: Facebook friends, description word count, FAQ count and Facebook buzz.

As mentioned above our research provides implications for reward-based CF intermediaries, too. Platforms in general act as intermediaries within the CF process by offering an appropriate IT structure for project initiators. Those structures benefit first-time users greatly to develop their campaign. In return CF platforms benefit from the success of the projects in many cases. Considering this, it is plausible that intermediaries offer tools that provide assistance to project initiators for the creation and execution of their projects. Essentially, the platform should allow backers, to easily navigate and search the platform for projects, including advanced search options, filtering, and sorting by categories. This also allows project initiators to draw inquiries from already completed projects, and helps them to learn from mistakes of these campaigns. Platforms can facilitate the project creation by providing guidelines for best practices via online tutorials, for example. These tutorials should reflect the platform's current state and up-to-date research. We advise platforms to communicate to project initiators that effective signals can be send in the pre-funding, in the funding-phase and in the post-funding phase (not considered in this study). Further, we advise platforms to inform project initiators about the effective low cost signals we have identified in our study.

Regarding the importance of project preparation, platforms should also develop tools that provide or integrate feedback mechanisms for CF projects which can serve as signals. This could include online forums, contact forms, or rating systems in which project initiators may solicit the opinions and advice of others to organize a campaign. Additionally, platforms could consider providing an analysis tool that uses main 
determiners of success to identify a project's likelihood of success. For the execution stages, platforms should acknowledge the importance of social media by enabling the easy integration of social networks (e.g., career networks), blogs and other social media into the campaign. Not only would this allow communication and interaction among the crowd but it would also help to spread information within the platform. This would probably further enhance recommendation mechanisms utilized by social network users and could connect users with projects that potentially interest them.

Finally, it should be noted that platforms influence a project's chances of success by highlighting projects based on separate popularity indexes or drop-down menus. The intermediaries should maintain a sense of responsibility while executing these measures, and ensure a neutral selection process. It is important that members do not feel slighted as a result of these selections. To summarize: functionalities, tools, or equal mechanisms that support a backer or shed light on a CF campaign can serve as external signals provided by the CF intermediary. These factors as well as internal signals can have an equal impact on a successful project completion.

Both, internal and external signals should be used in a CF campaign to attract and inform backers. This is increasingly important as the total number of initiated projects is continuously rising which makes it more difficult for individual projects to stand out from the crowd. As the number of scammed projects rises, shedding a bad light on honest projects (and even on CF in general), it further gets more important to convey trust. The results of this study can help project initiators to communicate with the crowd efficiently and thereby to generate trust.

\section{Limitations and future research}

This empirical study is subject to certain limitations which we will summarize in the following. The highlighted performance indicators have been observed in connection with the reward-based model. As mentioned in the beginning of this study, CF is generally classified into four different forms. Therefore, it is questionable if the results found in this study are applicable to other CF forms. Further, the results are based on data extracted from Kickstarter which is based on the all-or-nothing principle. The all-or-nothing principle refers to a rule frequently used by $\mathrm{CF}$ platforms which prescribes that project initiators only receive the money pledged by backers if they reach their funding target. Our results cannot be transferred to platforms using the keep-it-all principle under which project initiators receive money from backers independently of whether they reached their funding target. Finally, it should be mentioned that the information obtained via the web crawler are only a fraction of the factors influencing CF success. The success of a CF campaign is influenced by further characteristics, such as the quality of the idea or the interplay of different essential features.

Our results also provoke interesting questions for future research. Regarding the identified success factors, it would be interesting to investigate determinates of success across different $\mathrm{CF}$ forms and different platforms. Furthermore, an international comparison of communicational behavior and willingness to fund would be of interest. Considering the importance of social media in a CF project's 
success, an understanding of how this information is shared on social media would be useful. Hui et al. [41] report that project initiators struggle to assess the potential value of social media when planning and executing their campaigns. Therefore, it would be of interest to identify factors that convince social media users to share a project. For further entrepreneurial research, an important question is which CF model is most suitable for funding start-ups of different interests and idea stages. In this context, it would be crucial to know how to proceed with projects after successfully securing the funding. Another important question is related to fraud in reward-based CF [37]. Future research could further evaluate how fraud impacts backers' willingness to support CF projects, and how platform operators can help backers to identify such projects better.

\section{Conclusion}

$\mathrm{CF}$ has evolved over recent years as a successful alternative for raising capital within the finance industry. Thanks to $\mathrm{CF}$, which is the concept of accumulating a large sum of money by collecting smaller sums from several donors, the traditional boundaries of financing have expanded. Due to the founding gap, which is a challenge many start-ups face when attempting to gain capital, it is important to understand the mechanisms of reward-based CF that are crucial for a successful business venturing. Based on the systemization of the CF concept in general, the underlying analysis has investigated the effects of various influencing variables in form of signals on the funding target, which determine the success of CF projects. The analysis has been limited to the current state of CF projects and their rewardbased model, especially focusing on Kickstarter and data available on this platform. Hypotheses have been formed on the basis of different research streams, from startup and venturing, to market and e-commerce as well as psychological literature. Further, the hypotheses and their elaboration reflect and supplement the current state of research based on the fundamentals and determiners for success in reward-based $\mathrm{CF}$. Finally, and in its core, our elaborations are based on signaling theory, as the identified variables serve as signals to the backer in order to affect their funding behavior. Based on a web crawler, data from Kickstarter was extracted. In sum, 54,913 individual projects were analyzed by applying binary logistic regression analysis as a methodical instrument to evaluate the hypothesis. The performed regression analysis yielded the results and interdependencies displayed in Table 5.

Table 5 Overview of results and interdependencies (own illustration)

\begin{tabular}{ll}
\hline Variable/signals & Description \\
\hline $\begin{array}{l}\text { Length of } \\
\text { campaign }\end{array}$ & $\begin{array}{c}\text { Longer campaign durations (in days) are associated with a lower probability of } \\
\text { success of a reward based CF campaign }\end{array}$ \\
Updates & $\begin{array}{c}\text { More posted updates (number of updates), i.e. messages regarding changes to the } \\
\text { project's status, are associated with a higher probability of success of a reward based } \\
\text { CF campaign }\end{array}$ \\
An increase in reward levels (number of levels) for donations is associated with a \\
higher probability of success of a reward based CF campaign
\end{tabular}


Table 5 continued

Variable/signals Description

Popularity index Being featured in the staff-selected picks is associated with a higher probability of success of a reward based $\mathrm{CF}$ campaign

Social An increase in the number of connections a project initiator has on the social network networking Facebook (number of friends) is associated with a higher probability of success of a reward based $\mathrm{CF}$ campaign

Engagement An increase in the number of campaigns a project initiator supported (number of supportings) is associated with a higher probability of success of a reward based CF campaign

Delivery time Longer delivery times (in days) for the offered rewards are associated with a lower probability of success of a reward based CF campaign

Project An increase in the scope of a project description (number of words) is associated with description a higher probability of success of a reward based CF campaign

Images

An increase in the number of images used in a campaign presentation is associated with a higher probability of success of a reward based CF campaign

Videos

An increase in the number of embedded videos in the campaign presentation is associated with a higher probability of success of a reward based CF campaign

Homepage Linking to a homepage is associated with a higher probability of success of a reward based CF campaign

FAQ An increase in the number of answered questions (number of FAQ entries) in the project's FAQ section is associated with a higher probability of success of a reward based CF campaign

Preparation Longer preparation time (in days) is associated with a higher probability of success of a reward based CF campaign

Exclusivity Limiting quantities of rewards is associated with a lower probability of success of a reward based CF campaign

Social media An increase in comments and shares of the project's URL, as well as expressed buzz "Likes" (number of shares) is associated with a higher probability of success of a reward based $\mathrm{CF}$ campaign

\section{Appendix 1}

See Table 6.

Table 6 Literature review on success factors in reward-based CF (own elaboration)

\begin{tabular}{lllll}
\hline Source & $\begin{array}{l}\text { Criterion } \\
\text { for } \\
\text { success }\end{array}$ & Method & $\begin{array}{l}\text { Influencing } \\
\text { factors }\end{array}$ & Key findings \\
\hline $\begin{array}{c}\text { Agrawal et al. } \\
{[1]}\end{array}$ & $\begin{array}{c}\text { Funding } \\
\text { status }\end{array}$ & Quantitative analysis: & $\begin{array}{c}\text { Geographical } \\
\text { distance }\end{array}$ & $\begin{array}{c}\text { Campaigns can gain momentum by early } \\
\text { backings of family, friends and } \\
\text { followers }\end{array}$ \\
Regression analysis & $\begin{array}{c}\text { Investment } \\
\text { dynamics } \\
\text { disrupt the influence of geographical } \\
\text { boundaries between investors and } \\
\text { investees ("home bias") }\end{array}$ \\
\hline
\end{tabular}


Table 6 continued

\begin{tabular}{|c|c|c|c|c|}
\hline Source & $\begin{array}{l}\text { Criterion } \\
\text { for } \\
\text { success }\end{array}$ & Method & $\begin{array}{l}\text { Influencing } \\
\text { factors }\end{array}$ & Key findings \\
\hline $\begin{array}{l}\text { Belleflamme } \\
\text { et al. [9] }\end{array}$ & $\begin{array}{l}\text { Level of } \\
\text { funding }\end{array}$ & $\begin{array}{l}\text { Quantitative analysis: } \\
\text { Regression analysis }\end{array}$ & $\begin{array}{l}\text { Form of } \\
\text { organization }\end{array}$ & $\begin{array}{l}\text { Non-profit organizations are more } \\
\text { successful than for-profit organizations } \\
\text { Non-profit organizations also acquire } \\
\text { more capital than their for-profit } \\
\text { counterparts }\end{array}$ \\
\hline Carr [13] & $\begin{array}{c}\text { Funding } \\
\text { status }\end{array}$ & Quantitative analysis: & $\begin{array}{l}\text { Updates } \\
\text { Rewards } \\
\text { Social bonds }\end{array}$ & $\begin{array}{l}\text { Project updates have a positive impact on } \\
\text { the success of crowdfunding campaigns }\end{array}$ \\
\hline & & Regression analysis & & $\begin{array}{l}\text { The author states a connection between } \\
\text { the number of rewards offered and the } \\
\text { success of a campaign } \\
\text { The number of Facebook friends reflects } \\
\text { the potential of social interactions of the } \\
\text { project initiator with the crowd }\end{array}$ \\
\hline $\begin{array}{l}\text { Colombo } \\
\text { et al. [18] }\end{array}$ & $\begin{array}{c}\text { Funding } \\
\text { status }\end{array}$ & $\begin{array}{l}\text { Quantitative analysis: } \\
\text { Regression analysis }\end{array}$ & $\begin{array}{l}\text { Campaign } \\
\text { duration } \\
\text { Investment } \\
\text { dynamics } \\
\text { Rewards } \\
\text { Personal } \\
\text { attributes } \\
\text { Social bonds }\end{array}$ & $\begin{array}{l}\text { Positive cause-effect relationship between } \\
\text { project success and rewards that provide } \\
\text { a sense of belonging } \\
\text { Personal characteristics of project initiator } \\
\text { do matter in terms of success } \\
\text { Backing campaigns of other project } \\
\text { initiator can improve the funding } \\
\text { chances of one's own project due to the } \\
\text { fabrication of social capital }\end{array}$ \\
\hline $\begin{array}{l}\text { Cordova et al. } \\
\text { [20] }\end{array}$ & $\begin{array}{l}\text { Level of } \\
\text { funding }\end{array}$ & $\begin{array}{r}\text { Quantitative analysis: } \\
\text { Regression analysis }\end{array}$ & $\begin{array}{l}\text { Funding goal } \\
\text { Campaign } \\
\text { duration } \\
\text { Geographical } \\
\text { distance }\end{array}$ & $\begin{array}{l}\text { Projects with high funding goals have } \\
\text { lower chances of getting overfunded } \\
\text { Crowdfunding can help overcome the } \\
\text { "home bias" since investors base their } \\
\text { decisions on the quality of an } \\
\text { investment opportunity rather than on } \\
\text { geographical proximity }\end{array}$ \\
\hline $\begin{array}{l}\text { Cumming } \\
\text { et al. [23] }\end{array}$ & $\begin{array}{c}\text { Funding } \\
\text { status }\end{array}$ & $\begin{array}{l}\text { Quantitative analysis: } \\
\text { Regression analysis }\end{array}$ & $\begin{array}{l}\text { Mode of } \\
\text { payment }\end{array}$ & $\begin{array}{l}\text { All-or-nothing campaigns are more } \\
\text { successful than keep-it-all campaigns } \\
\text { Project initiators of All-or-nothing } \\
\text { campaigns provide more detailed } \\
\text { information to diminish the risk of } \\
\text { failing the funding goal }\end{array}$ \\
\hline $\begin{array}{l}\text { Frydrych et al. } \\
\text { [30] }\end{array}$ & $\begin{array}{c}\text { Funding } \\
\text { status }\end{array}$ & $\begin{array}{l}\text { Descriptive data } \\
\text { analysis }\end{array}$ & $\begin{array}{l}\text { Funding goal } \\
\text { Campaign } \\
\text { duration } \\
\text { Video message } \\
\text { Rewards } \\
\text { Personal } \\
\text { attributes }\end{array}$ & $\begin{array}{l}\text { The funding goal has an impact on project } \\
\text { success. Projects with a high funding } \\
\text { goal have lower chances of getting } \\
\text { funded } \\
\text { Projects founded by teams are more } \\
\text { successful than projects founded by just } \\
\text { one person }\end{array}$ \\
\hline $\begin{array}{l}\text { Giudici et al. } \\
\text { [33] }\end{array}$ & $\begin{array}{c}\text { Funding } \\
\text { status }\end{array}$ & $\begin{array}{l}\text { Quantitative analysis: } \\
\text { Regression analysis }\end{array}$ & $\begin{array}{l}\text { Social bonds } \\
\text { Geographical } \\
\text { distance }\end{array}$ & $\begin{array}{l}\text { The number of Facebook friends has a } \\
\text { positive effect on project success } \\
\text { Friends on social media can be interpreted } \\
\text { as social capital (help to gain } \\
\text { momentum) }\end{array}$ \\
\hline
\end{tabular}


Table 6 continued

\begin{tabular}{|c|c|c|c|c|}
\hline Source & $\begin{array}{l}\text { Criterion } \\
\text { for } \\
\text { success }\end{array}$ & Method & $\begin{array}{l}\text { Influencing } \\
\text { factors }\end{array}$ & Key findings \\
\hline $\begin{array}{l}\text { Hahn and Lee } \\
\text { [35] }\end{array}$ & $\begin{array}{c}\text { Funding } \\
\text { status }\end{array}$ & $\begin{array}{l}\text { Quantitative analysis: } \\
\text { Regression analysis }\end{array}$ & $\begin{array}{l}\text { Funding goal } \\
\text { Campaign } \\
\text { duration }\end{array}$ & $\begin{array}{l}\text { Campaign duration has a negative effect } \\
\text { on project success }\end{array}$ \\
\hline $\begin{array}{l}\text { Kuppuswamy } \\
\text { and Bayus } \\
{[50]}\end{array}$ & $\begin{array}{c}\text { Funding } \\
\text { status }\end{array}$ & $\begin{array}{l}\text { Quantitative analysis: } \\
\text { Panel logit model }\end{array}$ & $\begin{array}{l}\text { Investment } \\
\text { dynamics } \\
\text { Updates }\end{array}$ & $\begin{array}{l}\text { Funding is not linear. Projects receive } \\
\text { most pledges in the beginning and the } \\
\text { end (u-shape) } \\
\text { Updates have a positive impact on project } \\
\text { success }\end{array}$ \\
\hline $\begin{array}{l}\text { Leite and } \\
\text { Moutinho } \\
\text { [52] }\end{array}$ & $\begin{array}{l}\text { Level of } \\
\text { funding }\end{array}$ & $\begin{array}{l}\text { Quantitative and } \\
\text { qualitative analysis: } \\
\text { Regression analysis, } \\
\text { Descriptive data } \\
\text { analysis }\end{array}$ & $\begin{array}{l}\text { Updates } \\
\text { Rewards }\end{array}$ & $\begin{array}{l}\text { Updates have a positive impact on project } \\
\text { success } \\
\text { Negative cause-effect relationship } \\
\text { between number of rewards and } \\
\text { success, which suggests project } \\
\text { initiators to provide simple reward } \\
\text { structures }\end{array}$ \\
\hline $\begin{array}{l}\text { Marom and } \\
\text { Sade [56] }\end{array}$ & $\begin{array}{l}\text { Funding } \\
\text { status/ } \\
\text { Level of } \\
\text { funding }\end{array}$ & $\begin{array}{l}\text { Quantitative analysis: } \\
\text { Regression analysis, } \\
\text { Text mining }\end{array}$ & $\begin{array}{l}\text { Funding goal } \\
\text { Video message } \\
\text { Rhetoric } \\
\text { Experience }\end{array}$ & $\begin{array}{l}\text { Including a video message increases } \\
\text { chances of success } \\
\text { Giving detailed background information } \\
\text { on the project initiator has a positive } \\
\text { effect on success for artistic-creative } \\
\text { projects }\end{array}$ \\
\hline $\begin{array}{l}\text { Mitra and } \\
\text { Gilbert [63] }\end{array}$ & $\begin{array}{c}\text { Funding } \\
\text { status }\end{array}$ & $\begin{array}{l}\text { Quantitative analysis: } \\
\text { Regression analysis }\end{array}$ & Rhetoric & $\begin{array}{l}\text { Following the principles of persuasive } \\
\text { communication can help improve } \\
\text { project success }\end{array}$ \\
\hline Mollick [64] & $\begin{array}{c}\text { Funding } \\
\text { status }\end{array}$ & $\begin{array}{l}\text { Quantitative analysis: } \\
\text { Regression analysis }\end{array}$ & $\begin{array}{l}\text { Funding goal } \\
\text { Campaign } \\
\text { duration } \\
\text { Video message } \\
\text { Rhetoric } \\
\text { Updates } \\
\text { Social bonds } \\
\text { Geographical } \\
\text { distance } \\
\text { Popularity } \\
\text { indices }\end{array}$ & $\begin{array}{l}\text { Being presented in popularity indices } \\
\text { improves chances of getting funded } \\
\text { Positive cause-effect relationship between } \\
\text { the number of Facebook friends and } \\
\text { success } \\
\text { The number of updates improves project } \\
\text { success } \\
\text { Typos in the description lower success } \\
\text { chances, indicating the general quality } \\
\text { of a project } \\
\text { Having a video has a positive impact on } \\
\text { success } \\
\text { A long runtime decreases the chances of } \\
\text { project success }\end{array}$ \\
\hline $\begin{array}{l}\text { Pitschner and } \\
\text { Pitschner- } \\
\text { Finn [76] }\end{array}$ & $\begin{array}{c}\text { Funding } \\
\text { status }\end{array}$ & $\begin{array}{l}\text { Quantitative analysis: } \\
\text { Regression analysis }\end{array}$ & $\begin{array}{l}\text { Form of } \\
\text { organization }\end{array}$ & $\begin{array}{l}\text { Non-profit projects have a higher chance } \\
\text { of getting funded } \\
\text { The average pledge is higher for non- } \\
\text { profit projects compared to for-profit } \\
\text { projects }\end{array}$ \\
\hline Qiu [77] & $\begin{array}{c}\text { Funding } \\
\text { status }\end{array}$ & $\begin{array}{l}\text { Quantitative analysis: } \\
\text { Econometric model, } \\
\text { Two-sample } t \text { test }\end{array}$ & $\begin{array}{l}\text { Updates } \\
\text { Rewards } \\
\text { Popularity } \\
\quad \text { indices }\end{array}$ & $\begin{array}{l}\text { Being featured on crowdfunding platforms } \\
\text { helps raising pledges } \\
\text { Timely updates can help attracting new } \\
\text { backers }\end{array}$ \\
\hline Rao et al. [79] & $\begin{array}{c}\text { Funding } \\
\text { status }\end{array}$ & $\begin{array}{l}\text { Quantitative analysis: } \\
\text { Exploratory } \\
\text { analysis, Decision } \\
\text { tree models }\end{array}$ & $\begin{array}{l}\text { Investment } \\
\text { dynamics }\end{array}$ & $\begin{array}{l}\text { Reinforcement of the u-shaped pattern } \\
\text { regarding investment dynamics } \\
\text { The timing of pledges can be used to } \\
\text { forecast project success }\end{array}$ \\
\hline
\end{tabular}


Table 6 continued

\begin{tabular}{|c|c|c|c|c|}
\hline Source & $\begin{array}{l}\text { Criterion } \\
\text { for } \\
\text { success }\end{array}$ & Method & $\begin{array}{l}\text { Influencing } \\
\text { factors }\end{array}$ & Key findings \\
\hline Tirdatov [89] & $\begin{array}{l}\text { Funding } \\
\text { status/ } \\
\text { Level of } \\
\text { funding }\end{array}$ & $\begin{array}{l}\text { Qualitative analysis: } \\
\text { Text coding }\end{array}$ & Rhetoric & $\begin{array}{l}\text { The use of rhetorical appeals (ethos, } \\
\text { pathos, and logos) aims to help with } \\
\text { different goals } \\
\text { i.e., introducing testimonials as a mode of } \\
\text { persuasion can help building reputation } \\
\text { for the project initiator }\end{array}$ \\
\hline $\begin{array}{l}\text { Wash and } \\
\text { Solomon } \\
\text { [92] }\end{array}$ & $\begin{array}{c}\text { Funding } \\
\text { status }\end{array}$ & $\begin{array}{l}\text { Qualitative analysis: } \\
\text { Experiment }\end{array}$ & $\begin{array}{l}\text { Mode of } \\
\text { payment }\end{array}$ & $\begin{array}{l}\text { Depending on the mode of payment, } \\
\text { backers coordinate their actions more or } \\
\text { less } \\
\text { Backers are more willing to financially } \\
\text { support projects on All-or-nothing } \\
\text { platforms }\end{array}$ \\
\hline $\mathrm{Xu}$ et al. [94] & $\begin{array}{c}\text { Funding } \\
\text { status }\end{array}$ & $\begin{array}{l}\text { Quantitative analysis: } \\
\text { Regression analysis: } \\
\text { Latent } \\
\text { Dirichlet allocation } \\
\text { (LDA) }\end{array}$ & Updates & $\begin{array}{l}\text { Positive cause-effect relationship between } \\
\text { the number of Updates and success } \\
\text { Reminders, reports on progress, } \\
\text { announcing new rewards and the request } \\
\text { for promotion on social media have the } \\
\text { strongest impact }\end{array}$ \\
\hline $\begin{array}{l}\text { Zheng et al. } \\
\text { [95] }\end{array}$ & $\begin{array}{l}\text { Level of } \\
\text { funding }\end{array}$ & $\begin{array}{l}\text { Quantitative analysis: } \\
\text { Regression analysis }\end{array}$ & $\begin{array}{l}\text { Rhetoric } \\
\text { Social bonds }\end{array}$ & $\begin{array}{l}\text { The circle of friends on social media } \\
\text { functions as social capital. The number } \\
\text { of friends on Facebook has a positive } \\
\text { impact on crowdfunding success } \\
\text { Positive cause-effect relationship between } \\
\text { length of the project description and } \\
\text { success }\end{array}$ \\
\hline $\begin{array}{l}\text { Zvilichovsky } \\
\text { et al. [96] }\end{array}$ & $\begin{array}{c}\text { Funding } \\
\text { status }\end{array}$ & $\begin{array}{l}\text { Quantitative analysis: } \\
\text { Regression analysis }\end{array}$ & $\begin{array}{l}\text { Social bonds } \\
\text { Experience }\end{array}$ & $\begin{array}{l}\text { The backing of other projects helps } \\
\text { project initiators to increase chances of } \\
\text { success for their own project } \\
\text { Due to the authors, this is caused by the } \\
\text { principle of reciprocity, which is deeply } \\
\text { rooted in crowdfunding communities }\end{array}$ \\
\hline
\end{tabular}

For the literature review, the term "CF" was searched in major electronic databases (e.g., EBSCO, Wiley Online Library, and ACM Digital Library). The search results are narrowed down in an initial screening on the reward-based form of CF. Thereafter; seminar, bachelor and masters' theses were excluded

\section{Appendix 2}

See Figs. 2, 3 and 4. 


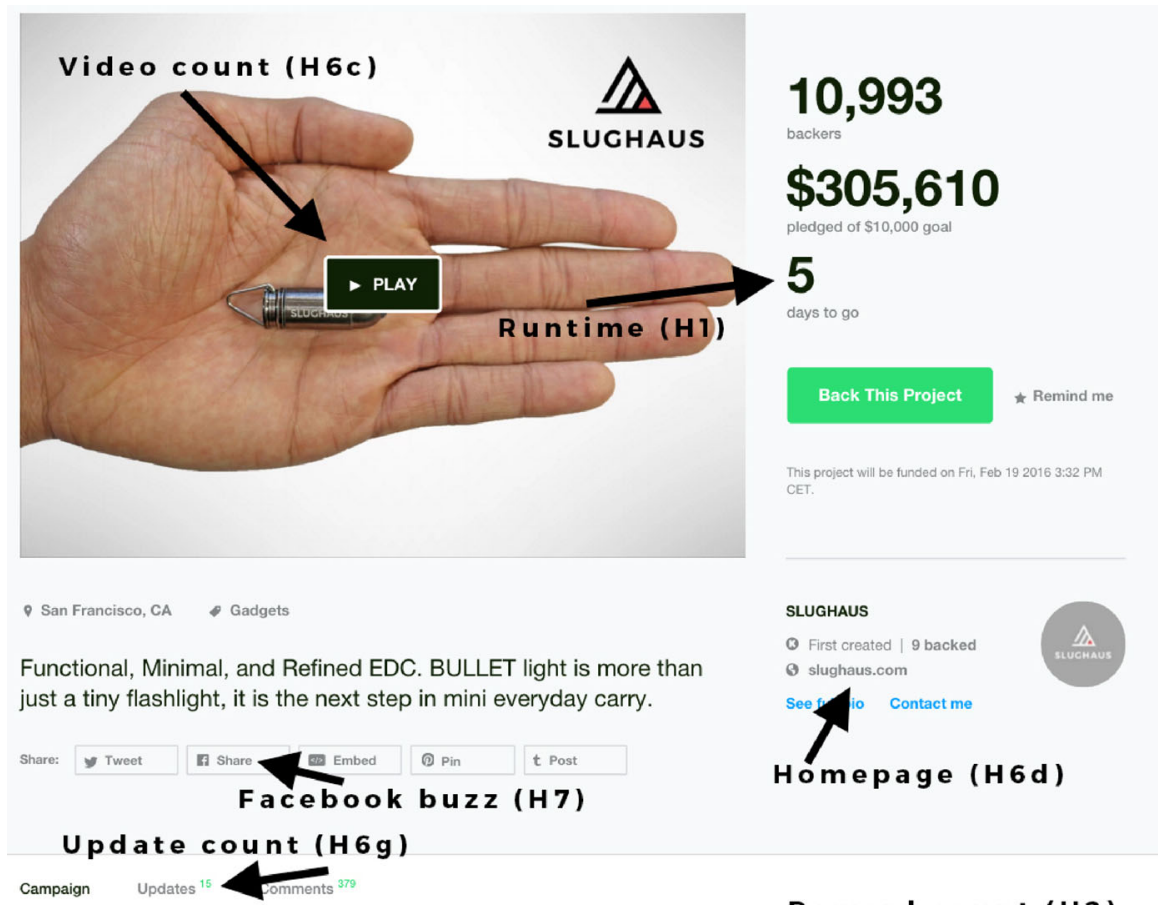

\section{Reward count (H2)}

Image count (H6b)

Pledge $\$ 9$ or more

o 272 backers

Lone Star II:

Average delivery

date ( H 5) Estimated delivery: Ships to:

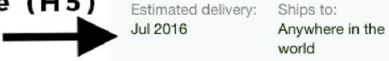

Reward

limit ( H 3 )

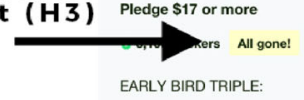

\section{Description word count (H6a)}

Light is essential in our everyday lives. We eed it to see-when in cars, when finding keyholes, even when we're outdoors. We he wo noticed that many everyday carry, or EDC, essentials are too dull, and current EDC fle fights are too big and bulky, so we set out to create our own.

\section{EARLY BIRD TRIPLE:}

3x BULLET lights of your choice.

Keep one in the car, at home, and on your keychain. Either share with a friend, or jus keep all! You decide.

FAQ

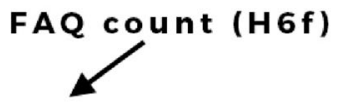

Have a question? If the info above doesn't help, you can ask the project creator directly.

\section{Ask a question}

Fig. 2 Variables from project website [49] 


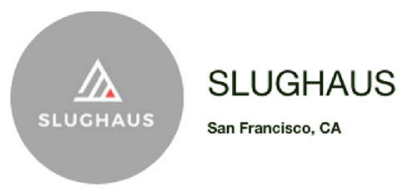

\title{
Facebook friends (H4a)
}

\begin{abstract}
SLUGHAUS is a small company with the sole mission of keeping your everyday carry functional and beautiful at all times. We hope that our products not only accompany your everyday carry
\end{abstract} essentials, but help simplify your lifestyle as a whole.

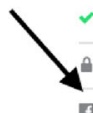

$\checkmark$ Jose Alfredo Chavez

Last login Feb 142016

If Not connected

Websites

Backed count (H4b)

slughaus.com

Fig. 3 Variables from initiator bio [49]

\section{Projects We Love staff picked (H8) sorted by End Date $\checkmark$}

Refine search

Explore 380 live projects

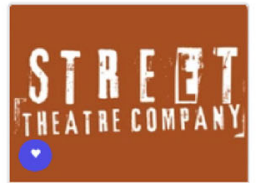

Help Get Street Theatre Off The Street

Jason Tucket

One of the most successfut

professional theaters in Nashville

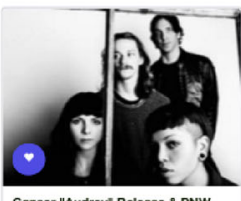

Ganser "Audrey" Release \& PNW 2016 Tour

Ganser plans their first physical release and Pacitic Northesest tour

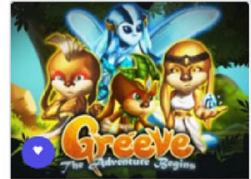

Greeve : The Adventure Begins Miracle Gates Studio

Beautiful 2D Action Adventure combine with RPG Mechanism in an Epic fantasy Worids with deep

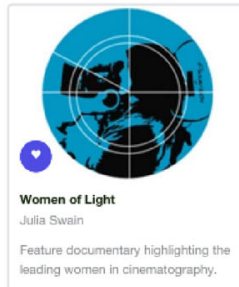

Feature dooumentary highlighting the

Fig. 4 Variables from staff picked webpage [48] 


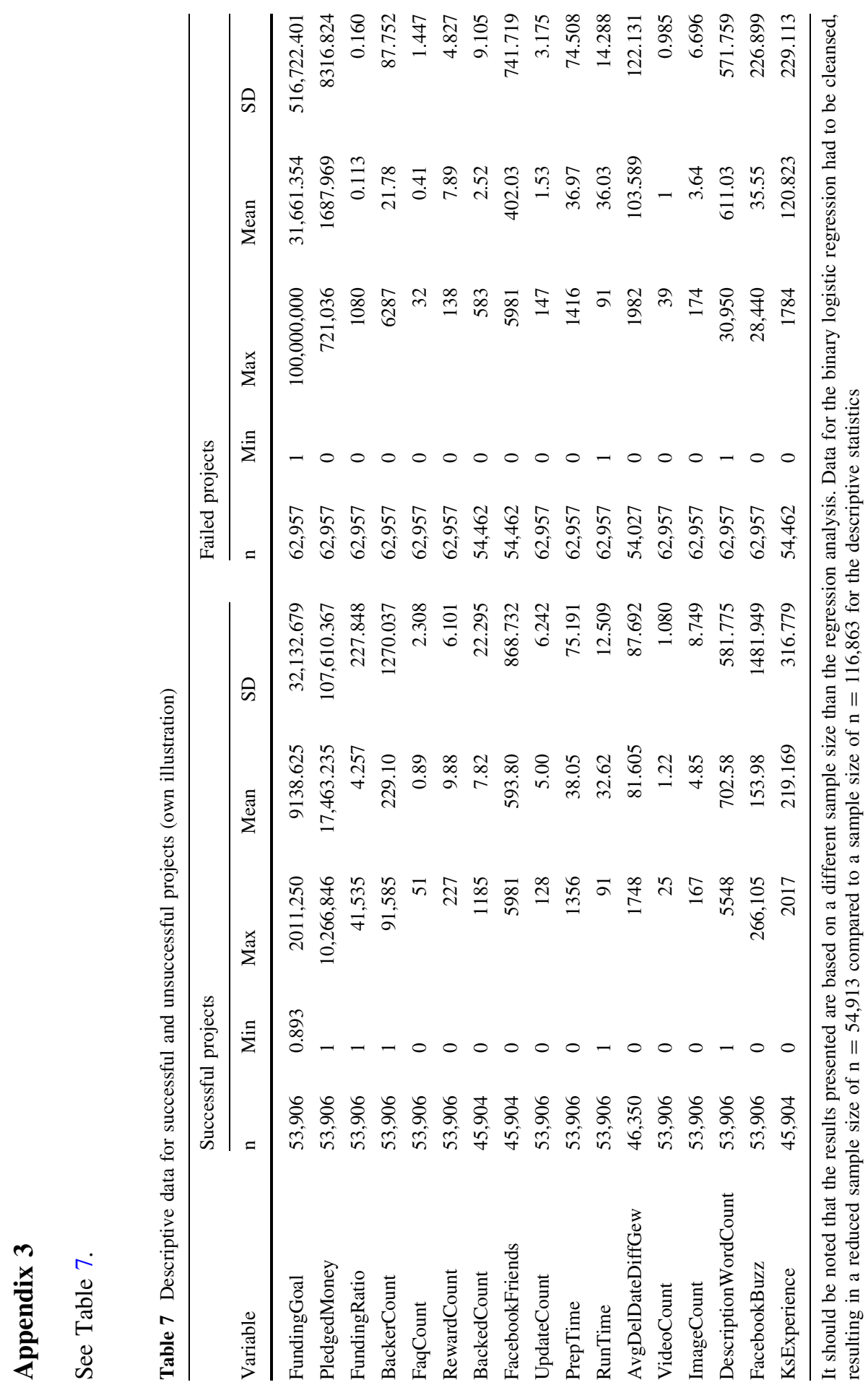




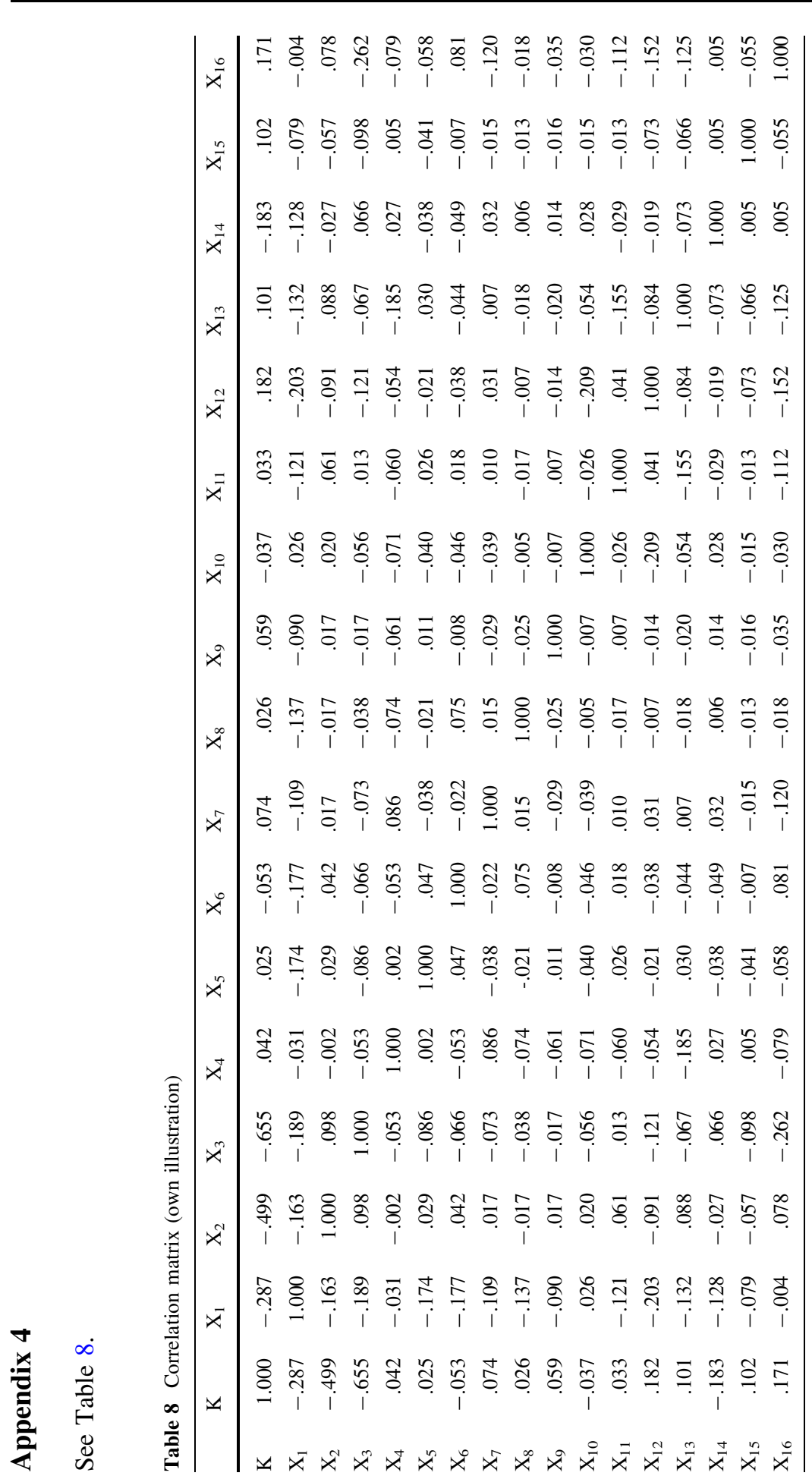




\section{References}

1. Agrawal, A., Catalini, C., \& Goldfarb, A. (2011). Friends, family, and the flat world: The geography of crowdfunding. NBER Working Paper 16820. Cambridge.

2. Agrawal, A., Catalini, C., \& Goldfarb, A. (2014). Some simple economics of crowdfunding. Innovation Policy and the Economy, 14(1), 63-97.

3. Amy, L. O., \& Dawn, I. (1998). The effect of guarantees on consumers' evaluation of servicesnull. Journal of Services Marketing, 12(5), 362-378.

4. Asur, S., \& Huberman, B. A. (2010). Predicting the future with social media. In IEEE/WIC/ACM International Conference on Web Intelligence and Intelligent Agent Technology (WI-IAT) (pp. 492-499), Los Alamitos

5. Baddeley, M. (2009). Herding, social influence and economic decision-making: socio-psychological and neuroscientific analyses. Philosophical Transactions of the Royal Society of London B: Biological Sciences, 365(1538), 281-290.

6. Bansal, H. S., \& Voyer, P. A. (2000). Word-of-mouth processes within a services purchase decision context. Journal of Service Research, 3(2), 166-177.

7. Beaulieu, T., Sarker, S., \& Sarker, S. (2015). A conceptual framework for understanding crowdfunding. Communications of the Association for Information Systems, 37(1), 1-31.

8. Belleflamme, P., Lambert, T., \& Schwienbacher, A. (2010). Crowdfunding: An industrial organization perspective. In workshop “digital business models: Understanding strategies”, Paris, Frankreich

9. Belleflamme, P., Lambert, T., \& Schwienbacher, A. (2013). Individual crowdfunding practices. Venture Capital, 15(4), 313-333.

10. Brock, T. C. (1968). Implications of commodity theory for value change. In A. G. Greenwald, T. C. Brock, \& T. M. Ostrom (Eds.), Psychological foundations of attitudes (pp. 243-275). New York: Academic.

11. Burtch, G., Ghose, A., \& Wattal, S. (2012). An empirical examination of the antecedents and consequences of investment patterns in crowd-funded markets. SSRN Electronic Journal.

12. Burtch, G., Ghose, A., \& Wattal, S. (2013). An empirical examination of the antecedents and consequences of investment patterns in crowd-funded markets. Information Systems Research, 24, 499-519.

13. Carr, S. (2013). Collective action and the financing of innovation: Evidence from crowdfunding. Darden Business School Working Paper No. 2450510. http://dx.doi.org/10.2139/ssrn.2450510. Accessed 21 Aug 2015.

14. Chen, Y.-H., Hsu, I. C., \& Lin, C.-C. (2010). Website attributes that increase consumer purchase intention: A conjoint analysis. Journal of Business Research, 63(9-10), 1007-1014.

15. Chen, X. P., Yao, X., \& Kotha, S. (2009). Entrepreneur passion and preparedness in business plan presentations: A persuasion analysis of venture capitalists' funding decisions. Academy of Management Journal, 52(1), 199-214.

16. Cholakova, M., \& Clarysse, B. (2015). Does the possibility to make equity investments in crowdfunding projects crowd out reward-based investments? Entrepreneurship Theory and Practice, 39(1), $145-172$.

17. Clark, C. (2008). The impact of entrepreneurs' oral 'pitch' Presentation skills on business angels' initial screening investment decisions. Venture Capital, 10(3), 257-279.

18. Colombo, M. G., Franzoni, C., \& Rossi-Lamastra, C. (2015). Internal social capital and the attraction of early contributions in crowdfunding. Entrepreneurship Theory and Practice, 39(1), 75-100.

19. Connelly, B. L., Certo, S. T., Ireland, R. D., \& Reutzel, C. R. (2011). Signaling theory: A review and assessment. Journal of Management, 37(1), 39-67.

20. Cordova, A. J. D., \& Gianfrate, G. (2013). The bearable lightness of crowdfunding: Evidences from technology projects. In 4th European Conference on corporate $R \& D$ and innovation, Sevilla

21. Cropanzano, R., \& Mitchell, M. S. (2005). Social exchange theory: An interdisciplinary review. Journal of Management, 31(6), 874-900.

22. Crosby, L. A., Evans, K. R., \& Cowles, D. (1990). Relationship quality in services selling: an interpersonal influence perspective. Journal of Marketing, 54(3), 68-81.

23. Cumming, D. J., Leboeuf, G., \& Schwienbacher, A. (2014). Crowdfunding models: Keep-it-all vs. all-or-nothing. SSRN Electronic Journal 
24. Dichter, E. (1966). How word-of-mouth advertising works. Harvard Business Review, 44(6), 147-166.

25. Drake, J. R., Hall, D. J., Cegielski, C., \& Byrd, T. A. (2015). An exploratory look at early online auction decisions: Extending signal theory. Journal of Theoretical and Applied Electronic Commerce Research, 10(1), 35-48.

26. Draper, N. R., \& Smith, H. (2014). Applied regression analysis (Wiley series in probability and statistics). New York: Wiley.

27. East, R., Hammond, K., \& Lomax, W. (2008). Measuring the impact of positive and negative word of mouth on brand purchase probability. International Journal of Research in Marketing, 25(3), 215-224.

28. Flanagin, A. J., Metzger, M. J., Pure, R., Markov, A., \& Hartsell, E. (2014). Mitigating risk in ecommerce transactions: perceptions of information credibility and the role of user-generated ratings in product quality and purchase intention. Electronic Commerce Research, 14(1), 1-23.

29. Fromkin, H. L. (1970). Effects of experimentally aroused feelings of undistinctiveness upon valuation of scarce and novel experiences. Journal of Personality and Social Psychology, 16(3), 521-529.

30. Frydrych, D., Bock, A. J., Kinder, T., \& Koeck, B. (2014). Exploring entrepreneurial legitimacy in reward-based crowdfunding. Venture Capital, 16(3), 247-269.

31. Gefen, D., Karahanna, E., \& Straub, D. W. (2003). Trust and TAM in online shopping: An integrated model. MIS Quarterly, 27(1), 51-90.

32. Gefen, D., \& Straub, D. W. (2004). Consumer trust in B2C e-commerce and the importance of social presence: Experiments in e-products and e-services. Omega, 32(6), 407-424.

33. Giudici, G., Guerini, M., \& Rossi Lamastra, C. (2013). Why crowdfunding projects can succeed: The role of proponents' individual and territorial social capital. http://dx.doi.org/10.2139/ssrn.2255944. Accessed 19 Aug 2015.

34. Gregg, D. G., \& Walczak, S. (2010). The relationship between website quality, trust and price premiums at online auctions. Electronic Commerce Research, 10(1), 1-25.

35. Hahn, J., \& Lee, G. (2013) Archetypes of crowdfunders' backing behaviors and the outcome of crowdfunding efforts: An exploratory analysis of kickstarter. In Conference on Information Systems and Technology (CIST 2013).

36. Hair, J. F. (2006). Multivariate data analysis. Upper Saddle River, NJ: Pearson Prentice Hall.

37. Hazen, T. L. (2012). Crowdfunding or fraudfunding? social networks and the securities laws-Why the specially tailored exemption must be conditioned on meaningful disclosure. North Carolina Law Review, 90(5), 1735-1770.

38. Hennig-Thurau, T., Gwinner, K. P., Walsh, G., \& Gremler, D. D. (2004). Electronic word-of-mouth via consumer-opinion platforms: what motivates consumers to articulate themselves on the internet? Journal of Interactive Marketing, 18(1), 38-52.

39. Herbig, P., \& Milewicz, J. (1993). The relationship of reputation and credibility to brand success. Journal of Consumer Marketing, 10(3), 18-24.

40. Herr, P. M., Kardes, F. R., \& Kim, J. (1991). Effects of word-of-mouth and product-attribute information of persuasion: An accessibility-diagnosticity perspective. Journal of Consumer Research, 17(4), 454-462.

41. Hui, J. S., Gerber, E. M., \& Gergle, D. (2014). Understanding and Leveraging Social Networks for Crowdfunding. In CHI ' 14 Extended Abstracts on Human Factors in Computing Systems, Toronto

42. Jansen, B. J., Zhang, M., Sobel, K., \& Chowdury, A. (2009). Twitter power: Tweets as electronic word of mouth. Journal of the American Society for Information Science and Technology, 60(11), 2169-2188.

43. Jiang, Z., \& Benbasat, I. (2007). Investigating the influence of the functional mechanisms of online product presentations. Information Systems Research, 18(4), 454-470.

44. Jiang, Z., Wang, W., \& Benbasat, I. (2005). Multimedia-based interactive advising technology for online consumer decision support. Communication of the ACM, 48(9), 93-98.

45. Johan, A., \& Nahid, S. (2000). The role of human web assistants in e-commerce: An analysis and a usability study. Internet Research, 10(2), 114-125.

46. Kickstarter.com (2011). Kickstarter blog: shortening the maximum project length. Accessed August 18, 2015. https://www.kickstarter.com/blog/shortening-the-maximum-project-length

47. Kickstarter.com (2015). Kickstarter blog: data. Accessed August 20, 2015 https://www.kickstarter. $\mathrm{com} / \mathrm{blog} /$ categories/data?ref=blog-p1

48. Kickstarter.com (2016). Staff picked. Accessed February 14, 2016 from https://www.kickstarter.com/ discover/recommended?ref=home_staff_picks 
49. Kickstarter.com (2016). BULLET I World's Smallest LED Flashlight. Accessed February 14, 2016 from https://www.kickstarter.com/projects/bullet/bullet-worlds-smallest-led-flashlight?lang=de

50. Kuppuswamy, V., \& Bayus, B. L. (2013). Crowdfunding creative ideas: The dynamics of project backers in kickstarter. UNC Kenan-Flagler Research Paper No. 2013-15. https://ssrn.com/abstract= 2234765. Accessed 21 Aug 2015.

51. Leclerc, F., Schmitt, B. H., \& Dubé, L. (1995). Waiting time and decision making: is time like money? Journal of Consumer Research, 22(1), 110-119.

52. Leite, P., \& Moutinho, N. (2012). Innovation through crowdfunding: A quantitative and qualitative analysis of kickstarter. In 13te internationalen CINet Konferenz: Continuous Innovation Across Boundaries

53. Lim, E., Tan, C.-W., Seo, D., Cyr, D., \& de Vries, K. (2013). An empirical investigation of the impact of online product presentation on hedonic web shopping. Milan: Special Interest Group on Human Computer Interaction (SIGHCI).

54. Lin, X., Featherman, M., \& Brooks, S. L. (2013). Factors affecting online consumer's behavior: An investigation across gender. In proceedings of the nineteenth americas conference on information systems, Chicago

55. Lindgaard, G., Fernandes, G., Dudek, C., \& Brown, J. (2006). Attention web designers: You have 50 milliseconds to make a good first impression! Behaviour \& Information Technology, 25(2), 115-126.

56. Marom, D., \& Sade, O. (2013). Are the life and death of a young start-up indeed in the power of the tongue? lessons from online crowdfunding pitches. SSRN Electronic Journal

57. Martens, M. L., Jennings, J. E., \& Jennings, P. D. (2007). Do the stories they tell get them the money they need? The role of entrepreneurial narratives in resource acqisition. Academy of Management Journal, 50(5), 1107-1132.

58. Mason, C. M., \& Harrison, R. T. (2004). Improving access to early stage venture capital in regional economies: A new approach to investment readiness. Local Economy, 19(2), 159-173.

59. Massolution (2015). 2015CF Crowdfunding industry report. Accessed November 24, 2015. http:// reports.crowdsourcing.org/index.php?route=product/product\&product_id=54

60. Mavlanova, T., Benbunan-Fich, R., \& Koufaris, M. (2012). Signaling theory and information asymmetry in online commerce. Information \& Management, 49(5), 240-247.

61. Menard, S. (2002). Applied logistic regression analysis (applied logistic regression analysis). Thousand Oaks: SAGE Publications.

62. Meyer, J., Gremler, D. D., \& Hogreve, J. (2014). Do service guarantees guarantee greater market value? Journal of Service Research, 17(2), 150-163.

63. Mitra, T., \& Gilbert, E. (2014). The language that gets people to give. In Proceedings of the 17th ACM conference on Computer supported cooperative work \& social computing (pp. 49-61), San Francisco

64. Mollick, E. (2014). The dynamics of crowdfunding: an exploratory study. Journal of Business Venturing, 29(1), 1-16.

65. Moss, T. W., Neubaum, D. O., \& Meyskens, M. (2015). The effect of virtuous and entrepreneurial orientations on microfinance lending and repayment: A signaling theory perspective. Entrepreneurship Theory and Practice, 39(1), 27-52.

66. Mowen, J. C., \& Mowen, M. M. (1991). Time and outcome valuation: implications for marketing decision making. Journal of Marketing, 55(4), 54-62.

67. Mullen, B., \& Johnson, C. (1990). The psychology of consumer behavior. Hillsdale: Lawrence Erlbaum Associates Inc.

68. Murray, K. B., \& Häubl, G. (2008). Interactive consumer decision aids. In B. Wierenga (Ed.), Handbook of marketing decision models (pp. 55-79). New York: Springer.

69. Nahapiet, J., \& Ghoshal, S. (1998). Social capital, intellectual capital, and the organizational advantage. The Academy of Management Review, 23(2), 242-266.

70. Ndofor, H. A., \& Levitas, E. (2004). Signaling the strategic value of knowledge. Journal of Management, 30(5), 685-702.

71. O'Keefe, R. M., \& McEachern, T. (1998). Web-based customer decision support systems. Communication of the ACM, 41(3), 71-78.

72. Palmer, J. W. (2002). Web site usability, design, and performance metrics. Information Systems Research, 13(2), 151-167.

73. Patton, M. A., \& Jøsang, A. (2004). Technologies for trust in electronic commerce. Electronic Commerce Research, 4(1-2), 9-21.

74. Phlips, L. (1983). The economics of price discrimination. Cambridge: Cambridge University Press. 
75. Pingjun, J., \& Bert, R. (2005). Customer intention to return online: Price perception, attribute-level performance, and satisfaction unfolding over time. European Journal of Marketing, 39(1/2), $150-174$.

76. Pitschner, S., \& Pitschner-Finn, S. (2014). Non-profit differentials in crowd-based financing: Evidence from 50,000 campaigns. Economics Letters, 123(3), 391-394.

77. Qiu, C. (2013). Issues in crowdfunding: theoretical and empirical investigation on kickstarter. http:// dx.doi.org/10.2139/ssrn.2345872. Accessed 20 Aug 2015.

78. Ranganathan, C., \& Ganapathy, S. (2002). Key dimensions of business-to-consumer web sites. Information \& Management, 39(6), 457-465.

79. Rao, H., Xu, A., Yang, X., \& Fu, W.-T. (2014). Emerging dynamics in crowdfunding campaigns. In social computing, behavioral-cultural modeling and prediction (Vol. 8393, pp. 333-340), Washington, DC

80. Riegner, C. (2007). Word of mouth on the web: the impact of web 2.0 on consumer purchase decisions. Journal of Advertising Research, 47(4), 436.

81. Sheth, J. N., Newman, B. I., \& Gross, B. L. (1991). Why we buy what we buy: A theory of consumption values. Journal of Business Research, 22(2), 159-170.

82. Sotiriadis, M. D., \& Zyl, C. V. (2013). Electronic word-of-mouth and online reviews in tourism services: the use of twitter by tourists. Electronic Commerce Research, 13(1), 103-124.

83. Spence, M. (1973). Job market signaling. The Quarterly Journal of Economics, 87(3), 355-374.

84. Spence, M. (2002). Signaling in retrospect and the informational structure of markets. The American Economic Review, 92(3), 434-459.

85. Steuer, J. (1992). Defining virtual reality: dimensions determining telepresence. Journal of Communication, 42(4), 73-93.

86. Stock, A., \& Balachander, S. (2005). The making of a "Hot Product": A signaling explanation of marketers' scarcity strategy. Management Science, 51(8), 1181-1192.

87. Taylor, S. E., \& Brown, J. D. (1994). Positive illusions and well-being revisited: Separating fact from fiction. Psychological Bulletin, 116(1), 21-27.

88. Thirumalai, S., \& Sinha, K. K. (2011). Customization of the online purchase process in electronic retailing and customer satisfaction: an online field study. Journal of Operations Management, 29(5), 477-487.

89. Tirdatov, I. (2014). Web-based crowd funding: rhetoric of success. Technical Communication, 61(1), 3-24.

90. Verhagen, T., Meents, S., \& Tan, Y.-H. (2006). Perceived risk and trust associated with purchasing at electronic marketplaces. European Journal of Information Systems, 15(6), 542-555.

91. Wan, W. W. N., Luk, C.-L., Fam, K.-S., Wu, P., \& Chow, C. W. C. (2012). Interpersonal relationship, service quality, seller expertise: How important are they to adolescent consumers? Psychology \& Marketing, 29(5), 365-377.

92. Wash, R., \& Solomon, J. (2014). Coordinating donors on crowdfunding websites. In 17th ACM conference on computer supported cooperative work and social computing (CSCW 2014) (pp. 38-48). Vancouver, BC

93. Wells, J. D., Valacich, J. S., \& Hess, T. J. (2011). What signal are you sending? How website quality influences perceptions of product quality and purchase intentions. MIS Quarterly, 35(2), 373-396.

94. Xu, A., Yang, X., Rao, H., Fu, W.-T., Huang, S.-W., \& Bailey, B. P. (2014). Show me the money! In ACM CHI conference on human factors in computing systems (pp. 591-600), Toronto, Canada

95. Zheng, H., Li, D., Wu, J., \& Xu, Y. (2014). The role of multidimensional social capital in crowdfunding: A comparative study in China and US. Information \& Management, 51(4), 488-496.

96. Zvilichovsky, D., Inbar, Y., \& Barzilay, O. (2013). Playing both sides of the market: Success and reciprocity on crowdfunding platforms. In 34th international conference on information systems (ICIS 2013). Milan, Italy. 